\title{
Greenhouse gas emissions from fen soils used for forage production in northern Germany
}

\author{
Arne Poyda ${ }^{1, a}$, Thorsten Reinsch ${ }^{1}$, Christof Kluß ${ }^{1}$, Ralf $\operatorname{Loges}^{1}$, and Friedhelm Taube ${ }^{1}$ \\ ${ }^{1}$ Institute of Crop Science and Plant Breeding, Grass and Forage Science/Organic Agriculture, \\ Kiel University, Hermann-Rodewald-Str. 9, 24118 Kiel, Germany \\ ${ }^{a}$ now at: Institute of Soil Science and Land Evaluation, Biogeophysics, Hohenheim University, \\ Emil-Wolff-Str. 27, 70593 Stuttgart, Germany \\ Correspondence to: Arne Poyda (a.poyda@uni-hohenheim.de)
}

Received: 10 December 2015 - Published in Biogeosciences Discuss.: 22 February 2016

Revised: 18 August 2016 - Accepted: 22 August 2016 - Published: 20 September 2016

\begin{abstract}
A large share of peatlands in northwestern Germany is drained for agricultural purposes, thereby emitting high amounts of greenhouse gases (GHGs). In order to quantify the climatic impact of fen soils in dairy farming systems of northern Germany, GHG exchange and forage yield were determined on four experimental sites which differed in terms of management and drainage intensity: (a) rewetted and unutilized grassland (UG), (b) intensive and wet grassland (GW), (c) intensive and moist grassland (GM) and (d) arable forage cropping (AR). Net ecosystem exchange (NEE) of $\mathrm{CO}_{2}$ and fluxes of $\mathrm{CH}_{4}$ and $\mathrm{N}_{2} \mathrm{O}$ were measured using closed manual chambers. $\mathrm{CH}_{4}$ fluxes were significantly affected by groundwater level (GWL) and soil temperature, whereas $\mathrm{N}_{2} \mathrm{O}$ fluxes showed a significant relation to the amount of nitrate in top soil. Annual balances of all three gases, as well as the global warming potential (GWP), were significantly correlated to mean annual GWL. A 2-year mean GWP, combined from $\mathrm{CO}_{2}-\mathrm{C}$ eq. of $\mathrm{NEE}, \mathrm{CH}_{4}$ and $\mathrm{N}_{2} \mathrm{O}$ emissions, as well as $\mathrm{C}$ input (slurry) and $\mathrm{C}$ output (harvest), was 3.8, 11.7, 17.7 and $17.3 \mathrm{MgCO}_{2}-\mathrm{Ceq}$. ha ${ }^{-1} \mathrm{a}^{-1}$ for sites $\mathrm{UG}, \mathrm{GW}, \mathrm{GM}$ and $\mathrm{AR}$, respectively (standard error (SE) 2.8, 1.2, 1.8, 2.6). Yield-related emissions for the three agricultural sites were 201, 248 and $269 \mathrm{~kg} \mathrm{CO}_{2}-\mathrm{C} \mathrm{eq}$. (GJ net energy lactation; NEL) ${ }^{-1}$ for sites GW, GM and AR, respectively (SE 17, 9, 19). The carbon footprint of agricultural commodities grown on fen soils depended on longterm drainage intensity rather than type of management, but management and climate strongly influenced interannual onsite variability. However, arable forage production revealed a high uncertainty of yield and therefore was an unsuit-
\end{abstract}

able land use option. Lowest yield-related GHG emissions were achieved by a three-cut system of productive grassland swards in combination with a high GWL (long-term mean $\leq 20 \mathrm{~cm}$ below the surface).

\section{Introduction}

Natural peatland ecosystems act as long-term carbon (C) sinks as $\mathrm{C}$ in plant residues accumulates due to anoxic conditions and thus incomplete decomposition (Joosten and Clarke, 2002). Globally, the amount of C stored in peatlands is about $446 \mathrm{Pg}$ ( $2 \mathrm{Pg}$ in German peatlands; Joosten, 2009), which is $24 \%$ higher compared to the number of $359 \mathrm{Pg} \mathrm{C}$ stored in global forest vegetation, given by Dixon et al. (1994). The drainage of peatlands causes aerobic soil conditions, leading to accelerated mineralization of the soil organic matter (SOM) and an increased release of $\mathrm{C}$ and nitrogen (N; Höper, 2002). Therefore, the natural sink for $\mathrm{C}$ and $\mathrm{N}$ is turned into a net source, converting drained peatlands to significant emitters of the greenhouse gases carbon dioxide $\left(\mathrm{CO}_{2}\right)$ and nitrous oxide $\left(\mathrm{N}_{2} \mathrm{O}\right.$; Kasimir-Klemedtsson et al., 1997; Maljanen et al., 2003b, 2010). Simultaneously, the methane $\left(\mathrm{CH}_{4}\right)$ emissions occurring under natural conditions are reduced to negligible levels (Roulet et al., 1993; van den Pol-van Dasselaar et al., 1997; Maljanen et al., 2003a).

In Germany, peatlands cover around 1.67 million ha (Joosten, 2009), which corresponds to $4.7 \%$ of the land area. Roughly $65 \%$ of these peatlands are minerotrophic fens (Grosse-Brauckmann, 1997) and around $70 \%$ is utilized for 
agricultural purposes (Röder and Osterburg, 2012). Peatlandrich regions, as particularly northwestern (NW) Germany (Lower Saxony, Schleswig-Holstein), show high shares of forage production and livestock units per hectare of utilized agricultural area, which is attributed to a concentration of dairy farming (Röder and Osterburg, 2012). Consequently, there is a high demand for intensive forage production to ensure the supply of a high-quality fodder. These management and cultivation practices require an intensive drainage and fertilization, leading to a continually increasing pressure on the utilization of German peatlands. The relevance of agriculturally utilized peatlands for the national GHG budget is highlighted as only $5 \%$ of the utilized agricultural area (Röder et al., 2011) but 50\% of the GHG emissions from agricultural soils (41.3 of $82.7 \mathrm{Tg} \mathrm{CO}_{2}$ eq.) are attributed to peatlands drained for agriculture (UBA, 2014).

Restoration of cultivated organic soils has one of the greatest GHG mitigation potentials in agriculture (Smith et al., 2008). The reestablishment of the natural peatland functioning can only be achieved by abandoning the drainage-based utilization, accompanied with a rewetting to natural hydrological conditions (Gorham and Rochefort, 2003; Höper et al., 2008; Zak et al., 2011). However, removing land from production provides maximum GHG mitigation, but might be rather an option for marginal lands than for regions with a high agricultural production value (Robertson et al., 2000). In those regions, it becomes fundamental to identify mitigation options that reduce GHG emissions without a distinct reduction of the agricultural productivity (Smith et al., 2008). Furthermore, the objective of climate protection measures for these areas should focus on resource use efficiency, i.e., minimizing GHG emissions per unit of product instead of unit area (Oenema et al., 2014). Here, we will focus on the net exchange of the three biogenic trace gases, $\mathrm{CO}_{2}, \mathrm{CH}_{4}$ and $\mathrm{N}_{2} \mathrm{O}$, from fen soils in an intensive dairy farming region of northern Germany (Schleswig-Holstein) and relate their annual budgets to forage energy yield (net energy lactation, NEL) of the specific sites.

There are several publications about the climatic relevance of peatlands and their corresponding emission factors (Byrne et al., 2004; Alm et al., 2007a; Drösler et al., 2008; Oleszczuk et al., 2008; Couwenberg, 2009b; Maljanen et al., 2010). In recent years, advanced information about the GHG fluxes from German peatlands is emerging (Drösler, 2005; Couwenberg, 2011; Beetz et al., 2013; Beyer and Höper, 2015; Leiber-Sauheitl et al., 2014). Nevertheless, GHG data for agricultural managed fen soils in northern Germany are lacking and their function for forage production has not been considered in calculations about GHG mitigation. Therefore, the recommended strategy for GHG reductions from drained peatlands is the rewetting to natural conditions or extensification (Couwenberg et al., 2011; Beetz et al., 2013). However, in terms of reducing GHG emissions per unit forage produced, Renger et al. (2002) and Regina et al. (2015) report consistently that an average groundwater table of $30 \mathrm{~cm}$ below the soil surface enables high-yielding grass cultivation and reduces the GHG emissions for a minimum of $40 \%$.

This study provides a full GHG balance as well as forage yields of fen soils in northern Germany in an intensive dairy farming region with different management strategies: (a) rewetted and unutilized grassland (UG), (b) intensive grassland wet $(\mathrm{GW})$, (c) intensive grassland moist, $(\mathrm{GM})$ and (d) arable forage production (AR) and the assumptions that

i. rewetting leads to a decrease in $\mathrm{CO}_{2}$ and $\mathrm{N}_{2} \mathrm{O}$ emissions but an increase in $\mathrm{CH}_{4}$ emissions,

ii. the GHG balances and $\mathrm{C}$ losses increase with land use intensity in the order $\mathrm{UG}>\mathrm{GW}>\mathrm{GM}>\mathrm{AR}$,

iii. product-related GHG emissions are higher for arable forage cropping on organic soils compared to grassland utilization, and

iv. wet but intensive grassland utilization (site GW) realizes the lowest product-related GHG emissions.

\section{Material and methods}

\subsection{Study area}

The study was conducted in a huge lowland area of Schleswig-Holstein, the most northern state of Germany, at $54^{\circ} 21^{\prime} \mathrm{N}$ and $9^{\circ} 24^{\prime} \mathrm{E}$. The long-term (1981-2010) mean annual temperature in this region was $8.7^{\circ} \mathrm{C}$ and mean annual precipitation was $861 \mathrm{~mm}$ (German Weather Service, meteorological station Erfde). The region was shaped by meltwater at the end of the last ice age (Weichsel glacial stage) that flowed through the valleys originated by the previous ice age (Saale glacial stage). Thereby, river systems were formed and as a result of sea level and groundwater rise, deep fen soils developed that grew up to peat bogs at some locations (Blume and Brümmer, 1986). For several centuries, the area has been drained for agricultural utilization. Traditionally, the fen soils of the study area have been used as grasslands for forage production in dairy farms. In the past 2 decades, about 15000 ha of the region have been allocated for nature conservation purposes. In these areas, the water levels were permanently raised and the agricultural utilization was extensified or abandoned (Rohman et al., 2008).

As a result of the ground level elevation as well as the status of the drainage system, the study area is irregularly drained, resulting in highly variable groundwater levels and thus intensity of peat degradation. According to these conditions, four sites were selected representing typical land use and drainage scenarios in this region. A rewetted and unutilized grassland site (UG) was chosen to evaluate the situation without agricultural activities. This site is located in a nature reserve area and was rewetted in 1991. There has been no utilization since 1998 and no fertilization since the rewetting. 
Table 1. Soil and land use characterization of the experimental sites (UG: unutilized grassland, GW: grassland wet, GM: grassland moist, AR: arable land). Numbers in brackets represent standard deviations.

\begin{tabular}{|c|c|c|c|c|}
\hline Site & UG (1 ha) & GW (3 ha) & GM (3.5 ha) & AR (2.2 ha) \\
\hline Peat depth $(\mathrm{cm})$ & 180 & 420 & 360 & 280 \\
\hline $\mathrm{C}_{\text {org }}(\%)^{\mathrm{a}}$ & $35.0(2.6)$ & $37.4(3.9)$ & $17.9(2.9)$ & $13.3(1.9)$ \\
\hline $\mathrm{C} / \mathrm{N}^{\mathrm{a}}$ & $17.7(1.0)$ & $15.7(0.6)$ & $12.4(0.4)$ & $12.2(0.2)$ \\
\hline $\operatorname{Ash}(\%)^{\mathrm{a}}$ & $36.8(11.7)$ & $33.6(6.3)$ & $68.7(2.3)$ & $74.0(4.2)$ \\
\hline Bulk density $\left(\mathrm{g} \mathrm{cm}^{-3}\right)^{\mathrm{a}}$ & $0.20(0.05)$ & $0.32(0.07)$ & $0.54(0.08)$ & $0.67(0.09)$ \\
\hline $\mathrm{C}$ stock $\left(\mathrm{Mg} \mathrm{ha}^{-1}\right)^{\mathrm{a}}$ & $215(57)$ & $361(82)$ & $289(45)$ & $266(38)$ \\
\hline $\mathrm{N}_{\min }\left(\mathrm{kg} \mathrm{ha}^{-1}\right)^{\mathrm{b}}$ & $20.8(8.8)$ & $44.7(22.7)$ & $73.1(37.3)$ & $65.3(31.4)$ \\
\hline $\mathrm{NO}_{3}-\mathrm{N}_{/} \mathrm{NH}_{4}-\mathrm{N}^{\mathrm{b}}$ & $0.10(0.16)$ & $0.25(0.27)$ & $0.67(0.61)$ & $2.55(3.34)$ \\
\hline Soil moisture $\left(\mathrm{kg} \mathrm{kg}^{-1}\right)^{\mathrm{b}}$ & $2.84(0.44)$ & $2.36(0.61)$ & $1.15(0.30)$ & $0.79(0.16)$ \\
\hline $\mathrm{pH}\left(\mathrm{CaCl}_{2}\right)^{\mathrm{c}}$ & $4.58(0.13)$ & $4.41(0.18)$ & $5.06(0.13)$ & $5.31(0.29)$ \\
\hline Groundwater level $(\mathrm{cm})^{\mathrm{d}}$ & $-10.9(3.5)$ & $-21.4(4.6)$ & $-33.0(9.4)$ & $-39.4(4.2)$ \\
\hline Fertilization $\left(\mathrm{kg} \mathrm{N} \mathrm{ha}^{-1} \mathrm{a}^{-1}\right)^{\mathrm{e}}$ & - & $300(240-400)$ & $260(230-320)$ & $150(130-170)$ \\
\hline Type of fertilizer ${ }^{\mathrm{f}}$ & - & cattle slurry, CAN, ASN & cattle slurry, CAN & cattle slurry, DAP, CAN \\
\hline Dominant plant species & $\begin{array}{r}\text { Purple small-reed } \\
\text { (Calamagrostis } \\
\text { canescens), } \\
\text { Reed canary grass } \\
\text { (Phalaris } \\
\text { arundinacea), } \\
\text { Common rush } \\
\text { (Juncus effusus) }\end{array}$ & $\begin{array}{r}\text { Rough bluegrass } \\
(\text { Poa trivialis }), \\
\text { Creeping bentgrass } \\
\text { (Agrostis stolonifera) }\end{array}$ & $\begin{array}{r}\text { Italian ryegrass } \\
\text { (Lolium } \\
\text { multiflorum), } \\
\text { Perennial ryegrass } \\
\text { (Lolium perenne), } \\
\text { Rough bluegrass } \\
\text { (Poa trivialis) }\end{array}$ & $\begin{array}{r}\text { Maize (Zea mays), } \\
\text { Barley } \\
\text { (Hordeum vulgare), } \\
\text { Wheat } \\
\text { (Triticum aestivum), } \\
\text { Perennial ryegrass } \\
\text { (Lolium perenne) }\end{array}$ \\
\hline
\end{tabular}

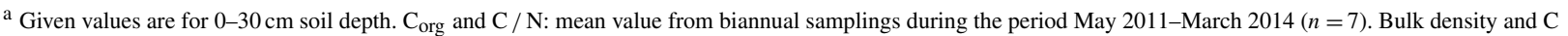
stock: mean value of soil samples taken in May $2013(n=4)$. Ash content: mean value from samples taken in October $2013(n=4) .{ }^{\mathrm{b}}$ Mean value of mineral nitrogen $\left(\mathrm{NO}_{3}^{-}\right.$and $\mathrm{NH}_{4}^{+}$) and gravimetric soil moisture content in $0-20 \mathrm{~cm}$ soil depth from biweekly samplings during the period April $2011-\mathrm{April} 2014$ ( $n=73$ ). ${ }^{\mathrm{c}}$ Mean value of two samplings in the beginning (May 2011) and in the end (July 2014) of the study $(n=8)$. ${ }^{\mathrm{d}}$ Mean value of linearly interpolated weekly measurements in the period April 2011-March $2014(n=4)$. ${ }^{\text {e }}$ Sum of applied nitrogen from organic and mineral fertilizers based on an average of 2011 , 2012 and 2013 and the range between the years. ${ }^{\mathrm{f}} \mathrm{CAN}=$ calcium ammonium nitrate, $\mathrm{ASN}=$ ammonium sulfate nitrate, $\mathrm{DAP}=$ diammonium phosphate.
}

The vegetation of site UG is typical for wet and nutrient-rich fallows, with a few dominant and productive species (Timmermann et al., 2006; Schrautzer et al., 2013). In contrast, the vegetation composition of the utilized grasslands (grassland wet, GW and grassland moist, GM) is dominated by species typical for intensively managed temperate grasslands (Table 1). The arable site (AR) was used as permanent grassland until conversion to silage maize production in 2007. In 2012, the cultivation changed to production of whole crop silage from spring barley and from spring wheat with undersown grass in 2013. The soil types of all sites are classified as histosols according to FAO (2006).

The utilized grassland sites were fertilized with slurry from dairy cattle. Typically, this was conducted shortly before the beginning of the growing season in a range of 20$30 \mathrm{~m}^{3} \mathrm{ha}^{-1}$ and subsequently after cutting events in a smaller range of $10-15 \mathrm{~m}^{3} \mathrm{ha}^{-1}$ if another cutting was designated. The arable site received 35 and $18 \mathrm{~m}^{3} \mathrm{ha}^{-1}$ of cattle slurry in 2011 and 2012, respectively. The slurry was deployed and incorporated into the top soil immediately before the sowing of the crops. In 2013, no slurry was applied. Additionally, the agricultural sites received mineral $\mathrm{N}$ fertilizers around the same dates as the slurry application, which occurs mostly in the form of calcium ammonium nitrate (CAN), containing $27 \%$ of $\mathrm{N}$. The total amounts of applied fertilizer $\mathrm{N}$ are displayed in Table 1.

\subsection{Site characteristics}

Air temperature, precipitation and photosynthetically active radiation (PAR) were measured at a climate station on site GW. When missing data occurred due to technical problems, data from a meteorological station of the DWD, located about $5 \mathrm{~km}$ from the sites, were used for gap filling. Soil temperatures in 5,10 and $15 \mathrm{~cm}$ depth of each site were continuously recorded every hour by soil temperature loggers (SL52T, IMEC, Heilbronn, Germany).

\subsubsection{Groundwater levels}

For continuous monitoring of GWLs, four perforated PVC tubes $(d=3 \mathrm{~cm}, l=120 \mathrm{~cm})$ were installed on each site in pairs at 5 and $15 \mathrm{~m}$ from the next drainage ditch. GWLs were recorded manually during every gas flux measurement campaign, leading to a minimum of one GWL record per week. For the calculation of mean annual GWLs, the recorded GWLs were linearly interpolated to obtain daily values and 
to avoid overestimation of periods with more frequent measurements.

\subsubsection{Soil properties}

For monitoring of soil mineral $\mathrm{N}$ status, soil samples were taken fortnightly with a soil auger at a depth of $0-20 \mathrm{~cm}$ on each site. Nitrogen was extracted with $0.01 \mathrm{M} \mathrm{CaCl}_{2}$ (VDLUFA, 1991) and the concentrations of nitrate $\left(\mathrm{NO}_{3}^{-}\right)$and ammonium $\left(\mathrm{NH}_{4}^{+}\right)$of the extractions were analyzed photometrically with a dual channel continuous flow analyzer (San ${ }^{++}$, Skalar Analytical B.V., Breda, The Netherlands). Mineral N stocks per hectare were calculated using the bulk density of the relevant sites. Bulk density was determined for the depths $5,15,25$ and $45 \mathrm{~cm}$ according to DIN ISO 11272 (HBU, 1998). The gravimetric water content of soil samples was estimated by oven drying at $105^{\circ} \mathrm{C}$ for $24 \mathrm{~h}$. To calculate the contents and amounts of $\mathrm{C}_{\text {org }}$ and $\mathrm{N}_{\text {tot }}$ of each site, soil sampling was conducted twice a year at soil depths of 0-30, 30-60 and 60-90 cm. After oven drying $\left(40^{\circ} \mathrm{C}\right.$ for 48-96 h), samples were analyzed with an elemental analyzer (Vario Max CN, Elementar, Hanau, Germany). As the peat soils were free of inorganic $\mathrm{C}$, the total $\mathrm{C}$ determined by the combustion method equaled the organic $\mathrm{C}$ content. The soil $\mathrm{pH}$ was determined before and after the study period in 2011 and 2014 according to VDLUFA (1991).

\subsubsection{Herbage yield and forage quality}

To quantify the herbage yields, the aboveground biomass (AGB) was cut shortly before harvest on three randomly selected spots with $0.25 \mathrm{~m}^{2}$ at a height of $5 \mathrm{~cm}$. The dry matter content of plants was determined after oven drying at $60^{\circ} \mathrm{C}$ for $48 \mathrm{~h}$. Subsequently, the material was ground using a centrifugal mill equipped with a $1 \mathrm{~mm}$ sieve (Cyclotech mill, Tecator, Foss, Hillerød, Denmark). Forage quality parameters were estimated by near infrared reflectance spectroscopy (NIRS; Baker and Barnes, 1990). Therefore, each sample was scanned with a NIR-System 5000 monochromator (FOSS, Silver Spring, USA). The NIRS calibrations were based on a sample pool selected to represent the entire spectral and chemical variability for which $\mathrm{N}$ concentrations were directly measured with an elemental analyzer (Vario Max CN, Elementar, Hanau, Germany). Net energy lactation (NEL) as the feed energy content available for maintenance and milk production was estimated as a function of metabolizable energy (ME) and crude ash content (Weißbach et al., 1996), whereas ME was calculated from the contents of enzyme soluble organic matter, crude ash, crude fat and acid detergent fiber according to GfE (2008).

\subsection{Determination of GHG fluxes and balances}

\subsubsection{Flux measurements}

$\mathrm{CH}_{4}$ and $\mathrm{N}_{2} \mathrm{O}$ fluxes were measured from April 2011 to March 2014 using closed manual chambers (Hutchinson and Mosier, 1981). Measurements were conducted weekly and in addition shortly after management practices like fertilization or tillage. At each site, eight PVC collars $(d=60 \mathrm{~cm}$, $h=15 \mathrm{~cm}$ ) were inserted $10 \mathrm{~cm}$ into the soil 1 week before the measurements started. To display gas fluxes for different GWLs at the same time, four collars were placed at 5 and $15 \mathrm{~m}$ from the next drainage ditch, respectively. When sites were harvested, the vegetation was removed from the collars. Site preparation measures were conducted in spring and the collars were shifted afterwards to obtain representative conditions. On site UG, a boardwalk was installed due to wet soil conditions and to avoid disturbances around the collars. For gas flux measurements, opaque PVC chambers ( $h=35 \mathrm{~cm}, V=0.1 \mathrm{~m}^{3}$ ) were used and chamber air samples were collected with a $30 \mathrm{~mL}$ syringe and stored in $12 \mathrm{~mL}$ pre-evacuated septum-capped vials (Labco, High Wycombe, UK; Glatzel and Well, 2008) 0, 15 and 30 min after chamber closure. Sampling was conducted between 09:00 and 12:00 (UTC + 1), as it has been shown that mean daily fluxes generally occur during this period of the day (Velthof and Oenema, 1995a; Petersen et al., 2012; van der Weerden et al., 2013). The samples were analyzed for concentrations of $\mathrm{CH}_{4}, \mathrm{~N}_{2} \mathrm{O}$ and $\mathrm{CO}_{2}$ with a gas chromatograph (7890a, Agilent Technology Inc., Santa Clara, CA, USA) equipped with a flame ionization detector (FID), electron capture detector (ECD) and thermal conductivity detector (TCD). Calibration of the gas chromatograph was performed with a minimum of three certified gas standards. Samples were injected using an autosampler (222 XL, Gilson Inc., Middleton, WI, USA). Data processing was conducted with the software Chem Station (Version B.01.04, Agilent Technology Inc., Santa Clara, CA, USA).

The $\mathrm{CO}_{2}$ exchange was determined according to the method of Drösler (2005). Elsgaard et al. (2012), Beetz et al. (2013) and Leiber-Sauheitl et al. (2014) present similar approaches. Here, static chambers with a diameter of $61 \mathrm{~cm}$ and a height of 35 were used. On each site, three PVC collars were installed. Measurement campaigns were conducted during the period March 2012 until April 2014 in intervals of 3-5 weeks. When harvest of the agricultural sites took place, the vegetation was removed from the collars and additional $\mathrm{CO}_{2}$ measurements were carried out few days after harvest. In total, the $\mathrm{CO}_{2}$ exchange was measured on 21, 28, 30 and 32 days at site UG, GW, GM and AR, respectively. Transparent and opaque chambers were used to measure the net ecosystem exchange (NEE) and the ecosystem respiration $\left(R_{\mathrm{ECO}}\right)$, respectively. The chambers were connected to an infrared gas analyzer (LI-820, LI-COR Biosciences, Lincoln, NE, USA) and a data logger (CR 1000, Campbell Scientific, 
Logan, UT, USA). $\mathrm{CO}_{2}$ concentration inside the chamber, temperature inside and outside the chamber and PAR outside the chamber were recorded every $5 \mathrm{~s}$. Chambers were equipped with a fan to ensure homogenization of the atmosphere inside the chamber headspace. When the vegetation was higher than the chambers, extensions $(h=35 \mathrm{~cm})$ were used. Due to the time lag between the maxima of PAR and temperature (air and soil), measurement campaigns were conducted from sunrise until afternoon to comprise the whole daily range of the driver variables. Maximum enclosure times were $120 \mathrm{~s}$ for NEE and $300 \mathrm{~s}$ for $R_{\mathrm{ECO}}$ measurements.

\subsubsection{Flux calculations}

Trace gas fluxes were calculated using linear regression for the change of gas concentration over time, as it has been described in several other studies (e.g., Flessa et al., 1998; Chatskikh et al., 2008; Beetz et al., 2013). Since effects of temperature and pressure inside the chamber induce only minor uncertainties to the measured fluxes (Levy et al., 2011), these variables are often neglected in flux calculations (Chatskikh et al., 2008). However, to quantify the uncertainty in calculated $\mathrm{CO}_{2}$ fluxes caused by a varying density of air as a function of temperature, $\mathrm{CO}_{2}$ fluxes $(n=5546)$ were corrected for the mean temperature inside the chamber and compared to the uncorrected fluxes. On average, temperature correction reduced calculated fluxes by $6 \%$ with a maximum reduction of $12 \%$ at a very high temperature of $38^{\circ} \mathrm{C}$. As temperature was not measured inside the chambers for $\mathrm{CH}_{4}$ and $\mathrm{N}_{2} \mathrm{O}$ flux measurements, the uncorrected $\mathrm{CO}_{2}$ fluxes were used for further analyses to ensure methodological consistency.

For $\mathrm{CH}_{4}$ and $\mathrm{N}_{2} \mathrm{O}$, fluxes were accepted when the coefficient of determination $\left(R^{2}\right)$ of the linear regression was $\geq 0.9$ to ensure a high accuracy of measured fluxes. Measurements with $R^{2}<0.9$ occurred mainly when chamber concentrations were near ambient and the corresponding fluxes were assumed to be zero. $\mathrm{CO}_{2}$ concentrations of the gas samples were used as control to identify erroneous $\mathrm{CH}_{4}$ and $\mathrm{N}_{2} \mathrm{O}$ values. If the $\mathrm{CO}_{2}$ concentration of a sample was not plausible (i.e., smaller than previous), the fluxes of $\mathrm{CH}_{4}$ and $\mathrm{N}_{2} \mathrm{O}$ were discarded from the data set (Leiber-Sauheitl et al., 2014). For NEE and $R_{\mathrm{ECO}}$ measurements, all fluxes with plausible concentration changes over time were accepted, irrespective of flux magnitude and the $R^{2}$ of linear regression (Alm et al., 2007b; Leiber-Sauheitl et al., 2014). To avoid underestimation of $\mathrm{CO}_{2}$ exchange by a diminishing concentration gradient between chamber headspace and soil or plant, and thus decreasing fluxes (Davidson et al., 2002), only the part of linear concentration change was used for flux calculation, which could be only $30 \mathrm{~s}$ for NEE measurements with highly productive vegetation and high PAR. Quality criteria for $\mathrm{CO}_{2}$ measurements were changes of chamber temperature by more than $1.5^{\circ} \mathrm{C}$ and a standard deviation of
PAR more than $10 \%$ of average PAR. Measurements that exceeded these threshold values were discarded.

\subsection{3 $\quad \mathrm{CO}_{2}$ modeling}

$R_{\text {ECO }}$ was estimated using a temperature-dependent flux model according to Lloyd and Taylor (1994):

$R_{\mathrm{ECO}}=R_{\mathrm{ref}} \cdot \exp \left[E_{0} \cdot\left(\frac{1}{T_{\mathrm{ref}}-T_{0}}-\frac{1}{T-T_{0}}\right)\right]$,

where $R_{\mathrm{ECO}}$ is the measured ecosystem respiration $\left(\mathrm{g} \mathrm{CO}_{2}-\right.$ $\left.\mathrm{C} \mathrm{m}^{-2} \mathrm{~h}^{-1}\right), R_{\text {ref }}$ is the respiration at reference temperature $\left(\mathrm{g} \mathrm{CO}_{2}-\mathrm{C} \mathrm{m}^{-2} \mathrm{~h}^{-1}\right), E_{0}$ is an activation-like parameter $(\mathrm{K})$, $T_{\text {ref }}$ is the reference temperature $(283.15 \mathrm{~K}), T_{0}$ is the temperature constant for the start of biological processes $(227.13 \mathrm{~K})$, and $T$ is the temperature with the best fit to the data of one measurement campaign. This could be either soil temperature in $5 \mathrm{~cm}$ depth at the corresponding site or the air temperature from the weather station at site GW. For modeling $R_{\mathrm{ECO}}, R_{\text {ref }}$ and $E_{0}$ were fitted for each plot and measurement campaign with soil or air temperature, depending on the level of significance. If neither soil temperature nor air temperature gave a significant relation to $R_{\mathrm{ECO}}$ of a measurement campaign, the data were pooled with those of one or two adjacent campaigns to obtain significant parameters for the $R_{\mathrm{ECO}}$ model (Beetz et al., 2013). However, for site UG it was in some cases not possible to calculate significant parameters. Therefore, the data set was separated into growing season and non-growing season according to Janssens (2010) and all measurement campaigns of a season were pooled. By this approach, the temporal resolution of the model was decreased, but the range of temperatures for which the model is valid was greatly increased. Nevertheless, for the agricultural sites it was necessary to consider the phenological development of the plants and especially the effect of harvest in the model. When fitting the model per campaign, the temperature range can be very narrow, which may lead to severe overestimations by the $R_{\mathrm{ECO}}$ model if the slope of regression is high and the temperature is above of the observed range. Therefore, the highest measured value of the corresponding campaign was set as a threshold for maximum $R_{\mathrm{ECO}}$. Every modeled value exceeding that threshold was recessed. The fitted parameters $R_{\text {ref }}$ and $E_{0}$ were linearly interpolated between the campaigns and $R_{\mathrm{ECO}}$ was modeled on an hourly basis using the corresponding temperature. To calculate gross primary production (GPP), the modeled $R_{\mathrm{ECO}}$ at the time of NEE measurements was subtracted from the measured NEE value.

GPP was modeled with PAR as an input variable using the rectangular hyperbola of Michaelis and Menten (1913):

$\mathrm{GPP}=\frac{\left(\mathrm{GP}_{\max } \cdot \alpha \cdot \mathrm{PAR}\right)}{\left(\mathrm{GP}_{\max }+\alpha \cdot \mathrm{PAR}\right)}$,

where GPP is the calculated gross primary production $\left(\mathrm{g} \mathrm{CO}_{2}-\mathrm{C} \mathrm{m}^{-2} \mathrm{~h}^{-1}\right), \mathrm{GP}_{\max }$ is the limit of carbon fixation for 
infinite PAR $\left(\mathrm{g} \mathrm{CO}_{2}-\mathrm{C} \mathrm{m}^{-2} \mathrm{~h}^{-1}\right), \alpha$ is the initial slope of the regression curve or light use efficiency $\left(\left(\mathrm{g} \mathrm{CO}_{2}-\mathrm{C} \mathrm{m}^{-2} \mathrm{~h}^{-1}\right)\right.$ $\left.\left(\mu \mathrm{mol} \mathrm{m}{ }^{-2} \mathrm{~s}^{-1}\right)^{-1}\right)$ and PAR is the average photon flux density of photosynthetically active radiation $\left(\mu \mathrm{mol} \mathrm{m}{ }^{-2} \mathrm{~s}^{-1}\right)$ that was determined during the NEE measurement by a quantum sensor (SKP 215, Skye Instruments, Llandrindod Wells, UK). PAR was corrected by a factor of 0.92 as a mean absorption by the transparent chambers of $8 \%$ was identified by measuring the PAR inside and outside the chambers at different light intensities. $\mathrm{GP}_{\max }$ and $\alpha$ were fitted for each plot and measurement campaign and linearly interpolated between the campaigns, assuming a consistent development of vegetation. However, as the plant biomass is harvested, $\mathrm{CO}_{2}$ uptake is interrupted immediately. Therefore, the parameters of the preceding measurement campaign, which was conducted only few days before harvest, were used until the cutting and then set back to zero. The subsequent campaign was conducted within 1 week after the cutting to capture the $\mathrm{CO}_{2}$ exchange of the recently harvested plants. GPP was modeled on an hourly basis using measured PAR from the weather station at site $\mathrm{GW}$.

\subsubsection{GHG and $C$ balances}

As the NEE of $\mathrm{CO}_{2}$ is the balance of $\mathrm{CO}_{2}$ uptake by plants (GPP) and the autotrophic and heterotrophic respiration of plants and soil ( $R_{\mathrm{ECO}}$; Chapin et al., 2006), NEE was calculated on an hourly basis as the sum of Eqs. (1) and (2):

$\mathrm{NEE}=\mathrm{GPP}+R_{\mathrm{ECO}}$.

For further processing, GPP, $R_{\mathrm{ECO}}$ and NEE were calculated per hectare and summed up to daily values $\left(\mathrm{kg} \mathrm{CO}_{2}-\right.$ $\mathrm{Cha}^{-1} \mathrm{~d}^{-1}$ ). The site-specific annual balances of the three components were calculated as the average of the 365-day sums of the three replicates. Annual $\mathrm{CH}_{4}$ and $\mathrm{N}_{2} \mathrm{O}$ balances were determined by plot-based linear interpolation between the measurement days and summation of daily values. Site-specific balances were calculated as average of the eight replicates. The global warming potential (GWP) of a specific site indicates to which magnitude it contributes to global warming, based on the GHG balance for a certain period. GWP was calculated using the IPCC (2007) radiative forcing factors of the individual gases for a time horizon of 100 years. These are 25 for $\mathrm{CH}_{4}$ and 298 for $\mathrm{N}_{2} \mathrm{O}$ related to $\mathrm{CO}_{2}\left(\mathrm{CO}_{2}\right.$ eq. $)$. Additionally, anthropogenic $\mathrm{C}$ inputs and losses via slurry application and harvest were calculated as $\mathrm{CO}_{2}$ eq. and included in the GWP (Beetz et al., 2013). Using the balances of $\mathrm{CO}_{2}-\mathrm{C}$ and $\mathrm{CH}_{4}-\mathrm{C}$ as well as the $\mathrm{C}$ import via slurry and $\mathrm{C}$ export via biomass harvest, the net ecosystem carbon balance (NECB) was calculated per site and year. For all $\mathrm{C}$ and GHG fluxes and balances, the atmospheric sign convention was applied, where all losses from the atmosphere into the ecosystem (site) are displayed as negative (the ecosystem acts as a sink) and all enrichments in the atmosphere are displayed as positive (the ecosystem acts as a source). This convention is transferred to the non-atmospheric fluxes like slurry application (negative) and biomass harvest (positive). GHG and carbon balances were calculated for the periods April 2012-March 2013 and April 2013-March 2014.

\subsection{Statistical analyses}

The statistical software R (2014) was used to evaluate the data. Evaluation started with the definition of an appropriate statistical mixed model (Laird and Ware, 1982; Verbeke and Molenberghs, 2000). The data were assumed to be normally distributed and heteroscedastic due to the different sites and measurement periods. These assumptions were based on a graphical residual analysis which was preferred to the application of pre-tests (Rasch et al., 2011). The statistical model included the site as a fixed factor. For daily $\mathrm{CH}_{4}$ fluxes, GWL and soil temperature in $5 \mathrm{~cm}$ were modeled as covariates, whereas for $\mathrm{N}_{2} \mathrm{O}$ fluxes, the amount of nitrate in $0-20 \mathrm{~cm}$ soil depth was used. The year was regarded as a random factor. Also, the correlations of the measurement values due to the day of sampling were taken into account. Based on this model, an analysis of covariance (ANCOVA) was conducted to test for significant influences of the covariates.

For balances of $\mathrm{CH}_{4}, \mathrm{~N}_{2} \mathrm{O}$ and $\mathrm{CO}_{2}$, as well as for the GWP, NECB and product-related GHG emissions, a mixed model with the site as fixed factor and the year as random factor was defined in each case. Heteroscedasticity was modeled due to the different sites and measurement periods. An analysis of variance (ANOVA) was conducted to identify significant differences between the sites. For the yields of DM, $\mathrm{C}, \mathrm{N}$ and NEL, the model was amplified by the year as a fixed factor instead of random factor. Furthermore, multiple contrast tests (Bretz et al., 2011) were conducted in order to identify significant differences between sites and years, respectively.

To evaluate the influence of GWL on the different trace gas balances and the total GWP, NECB and product-related GHG emissions, mean annual GWL was added as a fixed factor to the model used for the $t$ test. This model was calculated with and without the interaction term of site and GWL, as well as irrespective of the different sites. These three model types were compared referring to their Akaike information criterion (AIC; Akaike, 1974) to assess which model gives the best estimate for the relation between GWL and the corresponding variable. For $\mathrm{CH}_{4}$ and $\mathrm{N}_{2} \mathrm{O}$ balances, this procedure was conducted for mean annual GWL and, in terms of $\mathrm{N}_{2} \mathrm{O}$, for mean annual soil nitrate.

For uncertainty analysis of the $\mathrm{CO}_{2}$ model, a Monte Carlo simulation was conducted for each measurement plot and site. Therefore, model parameters with the same variation as the original values were randomly calculated for every measurement campaign or pooled data set and new regressions with temperature $\left(R_{\mathrm{ECO}}\right)$ and PAR (GPP) were fitted. Only regressions with realistic parameters were accepted $\left(E_{0}\right.$ and 


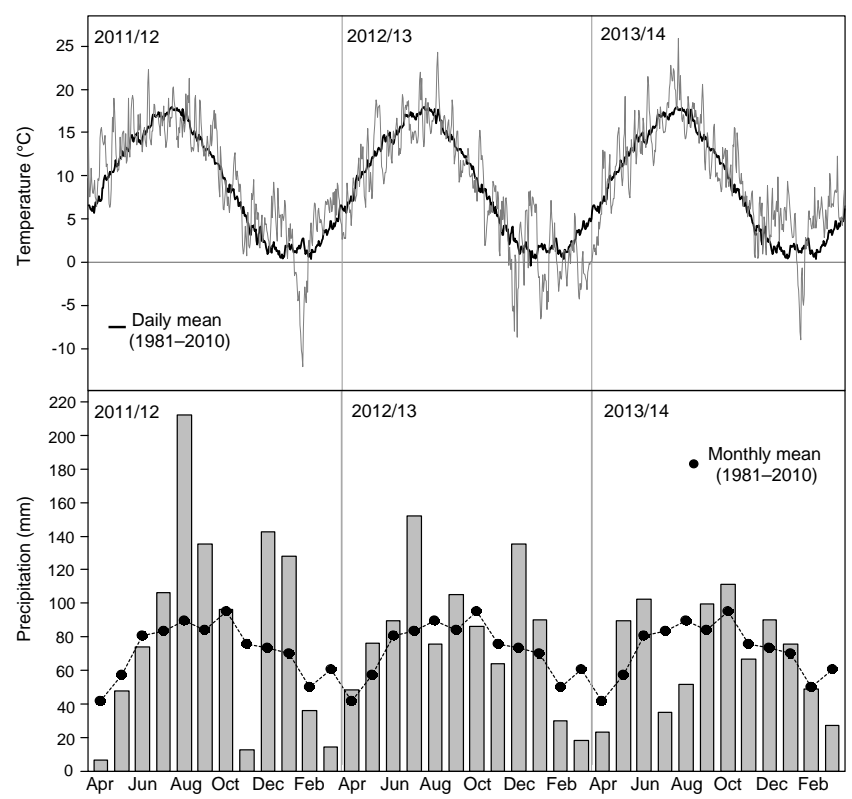

Figure 1. Daily mean air temperatures (grey line) and monthly mean precipitation sums (grey bars) during the study period (April 2011-March 2014) compared to the long-term averages.

$R_{\text {ref }} \geq 0, \alpha$ and $\mathrm{GP}_{\max } \leq 0$ ). This procedure was conducted 10000 times, thus, 10000 different model outputs for $R_{\mathrm{ECO}}$, GPP and NEE were obtained. The variation of these randomly calculated model outputs represents the uncertainty that is caused by the chamber measurements and by the fitting and linear interpolation of different numbers of measurement campaigns per plot and year. Since this procedure is conducted for each plot, the uncertainty can be calculated as the sum of mean variance of the three plots per site and the variance resulting from averaging the three replicates. This uncertainty was used for comparison of means obtained by the original simulation. Leiber-Sauheitl et al. (2014) present a similar approach.

\section{Results}

\subsection{Weather conditions}

Comparing the air temperature of the study periods to the long-term average $\left(8.7^{\circ} \mathrm{C}\right)$, the first period $(2011 / 12)$ was warmer $\left(9.6^{\circ} \mathrm{C}\right)$, the second period $(2012 / 13)$ was colder $\left(8.1^{\circ} \mathrm{C}\right)$ and the third period $(2012 / 14)$ was warmer again $\left(9.8^{\circ} \mathrm{C}\right)$. The precipitation sums of the first two study periods (1012 $\mathrm{mm}$ in 2011/12 and $971 \mathrm{~mm}$ in 2012/13) were higher than the long-term annual precipitation sum $(861 \mathrm{~mm})$, whereas precipitation was lower in the third study period (821 mm).

Considerable differences between the three periods are consisting in days with mean temperatures below $0{ }^{\circ} \mathrm{C}$ (Fig. 1). While in the first and third winter only one pe- riod with 20 and 11 frost days, respectively, occurred, several freeze-thaw events and, in total, 58 days with mean temperatures below the freezing point appeared in the second winter. Therefore, in 2013 the vegetation period started about 1 month later than in 2012 and 2014. High precipitation events took place in August 2011, leading to a precipitation sum of $236 \%$ the long-term average for this month (Fig. 1). Above-average precipitation also occurred in July $2012(183 \%)$, whereas in summer 2013 only 41 and $58 \%$ of long-term average precipitation were registered in July and August, respectively.

\subsection{Groundwater levels}

Groundwater levels (GWLs) during the study period showed high variability between sites and years (Fig. 2). Highest fluctuations were recorded on sites GM and AR with the same minima and maxima of -88 and $2 \mathrm{~cm}$, respectively. Variability was lower at sites UG and GW with minima of -56 (UG) and $-65 \mathrm{~cm}(\mathrm{GW})$ and maxima of $8(\mathrm{UG})$ and $2 \mathrm{~cm}(\mathrm{GW})$ for the 3-year period. Also short-term fluctuations with GWLs close to the soil surface and deep water levels within a few days or weeks were more distinct at sites GM and AR. In summers 2011 and 2012, all sites showed high GWLs close to the surface and even periods of inundation at site UG, whereas in summer 2013 GWLs were considerably lower (Fig. 2).

\subsection{GHG fluxes}

\subsubsection{Methane $\left(\mathrm{CH}_{4}\right)$}

Daily methane fluxes were highest at site UG and low at the agricultural sites (Fig. 3). While the intensively drained sites GM and AR showed negligible $\mathrm{CH}_{4}$ exchange; $\mathrm{CH}_{4}$ fluxes were on a higher level at site $\mathrm{GW}$ with one distinct emission peak in April 2013. $\mathrm{CH}_{4}$ emissions from site UG showed high spatial and temporal variability. Emissions increased for the first time in August 2011, followed by a continuous release of $\mathrm{CH}_{4}$ until July 2013. Highest emission peaks were recorded in summer 2012 and after that high releases occurred in autumn 2012 and spring 2013. Remarkably, the $\mathrm{CH}_{4}$ flux pattern at site UG changed substantially in July 2013 as emissions ceased and did not rise again until the end of the study period in spring 2014.

\subsubsection{Nitrous oxide $\left(\mathrm{N}_{2} \mathrm{O}\right)$}

$\mathrm{N}_{2} \mathrm{O}$ fluxes during the 3-year period showed no distinct regularity at the unutilized site (UG), whereas the agricultural sites showed seasonal flux patterns with several emission peaks during spring, mainly occurring after $\mathrm{N}$ fertilization (Fig. 4). While emissions at site UG peaked in May 2013, the highest $\mathrm{N}_{2} \mathrm{O}$ releases from site $\mathrm{GW}$ were observed in April 2012. Similar but more frequent emission peaks were recorded at site GM in April and May 2012 and 2013 and fur- 


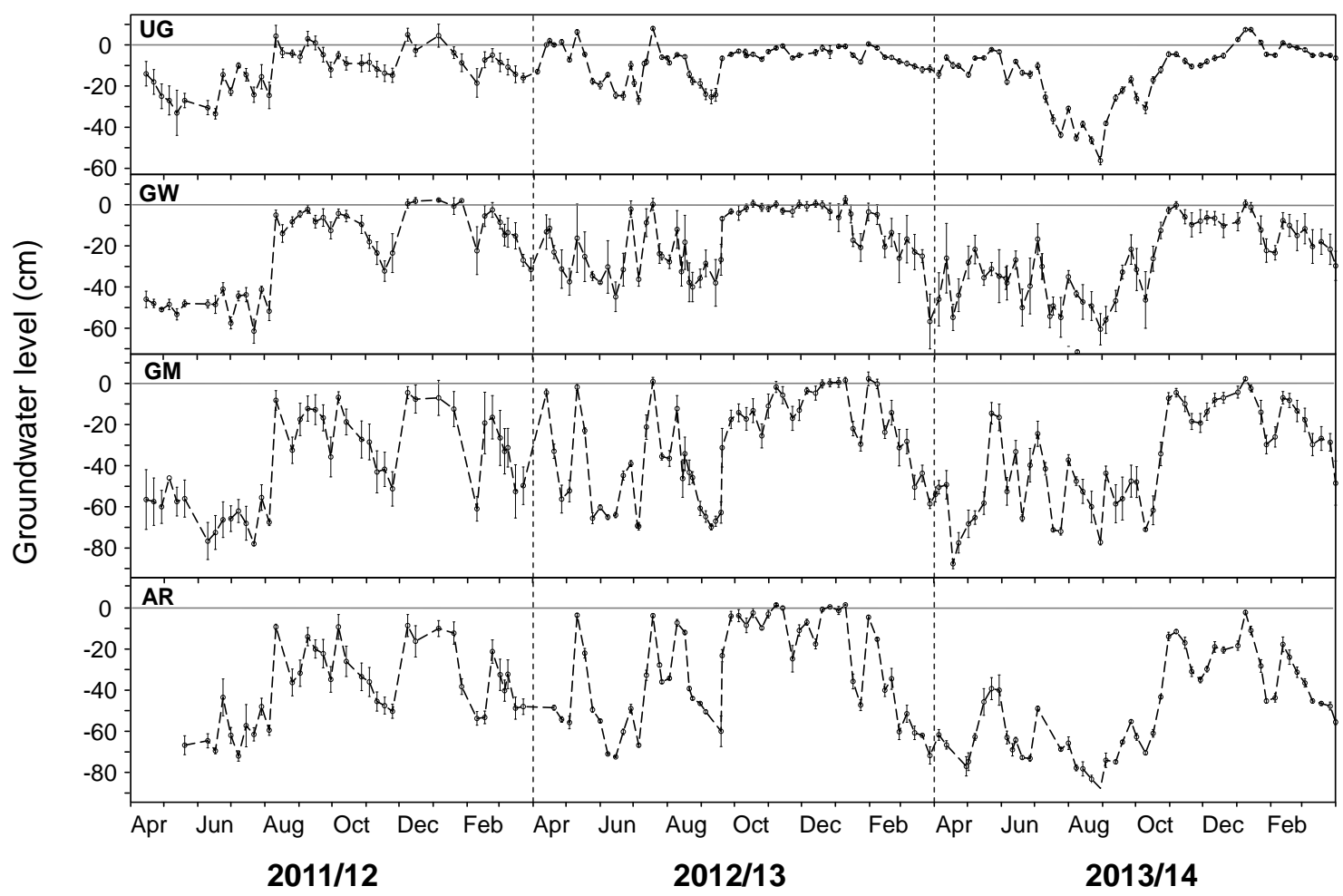

Figure 2. Development of GWLs at the four study sites during the study period (April 2011-March 2014). Displayed are mean values \pm standard errors of the manually recorded GWLs during gas flux measurements $(n=4)$.

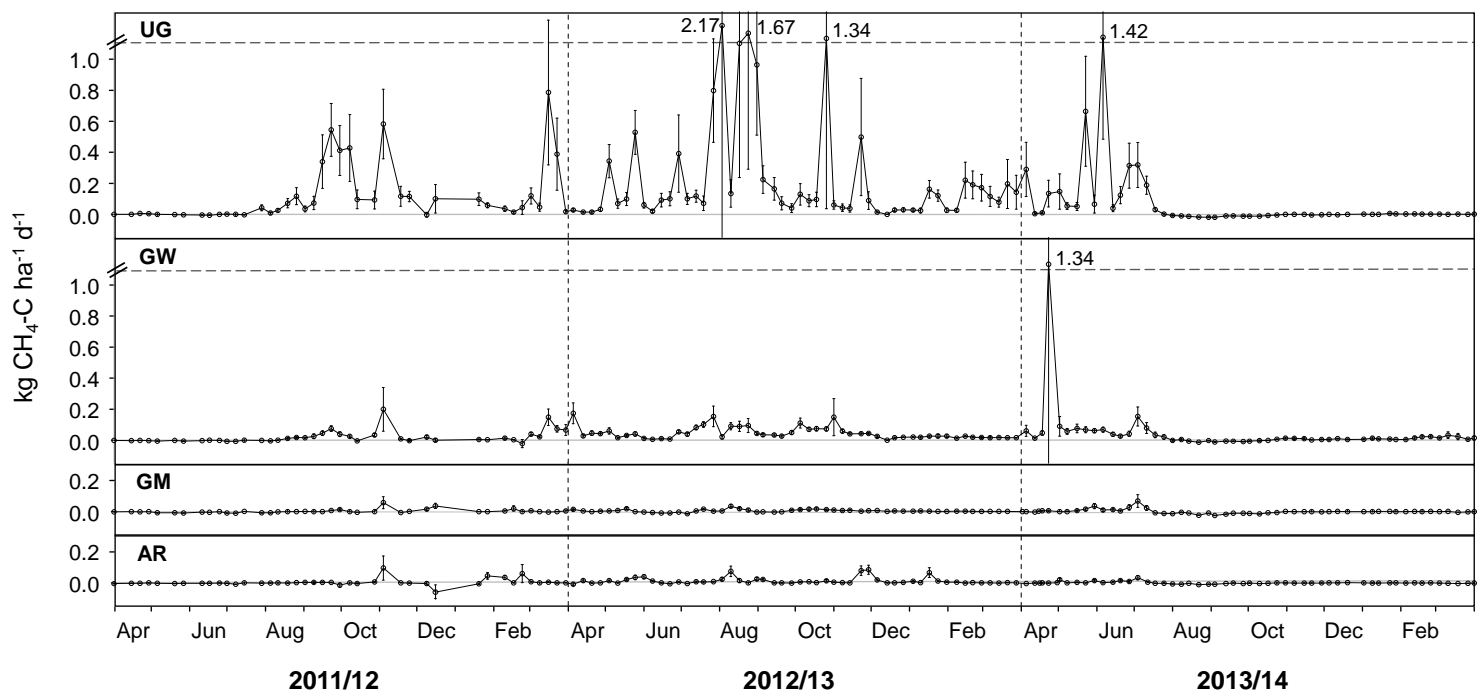

Figure 3. $\mathrm{CH}_{4}$ exchange at the four study sites during the study period (April 2011-March 2014). Values are displayed as mean \pm standard error $(n=8)$. Note the broken $y$ axis for sites UG and GW.

ther distinct $\mathrm{N}_{2} \mathrm{O}$ releases from that site were observed in autumn and winter 2013. The most pronounced seasonality of $\mathrm{N}_{2} \mathrm{O}$ emissions was determined at the arable site (AR) with high releases at the beginning of each study period. Thereby, the emissions in May 2013 clearly exceeded those of the preceding 2 years.

\subsubsection{Carbon dioxide $\left(\mathrm{CO}_{2}\right)$}

The carbon dioxide exchange of the study sites was characterized by seasonal patterns of GPP and ecosystem respiration $\left(R_{\mathrm{ECO}}\right)$ with high exchange rates during the vegetation period and smaller fluxes between October and April (Fig. 5). 
Maximum $\mathrm{CO}_{2}$ uptake rates were $-176,-188,-228$ and $-320 \mathrm{~kg} \mathrm{CO}_{2}-\mathrm{Cha}^{-1} \mathrm{~d}^{-1}$ for sites UG, GW, GM and AR, respectively (SE 9, 7, 17, 11). While this maximum $\mathrm{C}$ fixation took place in July 2013 at site UG, the two utilized grassland sites showed highest productivity in May 2012 before the first cutting. At site $\mathrm{AR}$, maximum $\mathrm{CO}_{2}$ uptake was modeled for the spring barley in June 2012. After the harvest of barley in August 2012, weeds remained that were eliminated by pesticides and mulched in September, so no $\mathrm{CO}_{2}$ uptake could occur until emergence of newly seeded plants in May 2013. Maximum modeled $\mathrm{CO}_{2}$ releases by $R_{\mathrm{ECO}}$ from sites UG, GW, GM and AR were 156 (August 2012), 231 (May 2012), 216 (August 2012) and $259 \mathrm{~kg} \mathrm{CO}_{2}-\mathrm{C} \mathrm{ha}^{-1} \mathrm{~d}^{-1}$ (June 2012), respectively (SE 16, 6, 2, 11). Depending on the extent of daily GPP and $R_{\mathrm{ECO}}$ fluxes, the sites can act as a net source or sink for $\mathrm{CO}_{2}$. For a total of 2 years (730 days), sites UG, GW, GM and AR acted as a $\mathrm{CO}_{2}$ sink on 182, 156, 102 and 115 days, whereas they showed a net $\mathrm{CO}_{2}$ release on 548, 574, 628 and 615 days, respectively (Fig. 5).

\subsection{GHG balances, NECB and GWP}

\subsection{1 $\mathrm{CH}_{4}$ and $\mathrm{N}_{2} \mathrm{O}$ balances}

Over the 3-year study period, mean annual $\mathrm{CH}_{4}$ emissions were 55.1, 13.5, 0.9 and $1.8 \mathrm{~kg} \mathrm{CH}_{4}-\mathrm{Cha}^{-1} \mathrm{a}^{-1}$ for sites $\mathrm{UG}, \mathrm{GW}, \mathrm{GM}$ and AR, respectively (SE 17.2, 4.0, 0.5, 0.7). Highest annual $\mathrm{CH}_{4}$ release occurred at site UG in the second year, while minimum budgets were determined for sites GM and AR in the third year (Table 2). However, due to the low fluxes at sites GM and AR, cumulated annual $\mathrm{CH}_{4}$ emissions were not significantly different from zero $(p>0.05)$. Sites GW and UG represented sources for $\mathrm{CH}_{4}$ with significantly higher releases at site UG that also showed the highest variation in annual $\mathrm{CH}_{4}$ budgets (Fig. 6a). Mean annual $\mathrm{N}_{2} \mathrm{O}$ balances of the four sites increased in the order $\mathrm{UG}, \mathrm{GW}$, $\mathrm{GM}$ and AR, accounting for 3.4, 6.5, 14.4 and $18.9 \mathrm{~kg} \mathrm{~N}_{2} \mathrm{O}-$ $\mathrm{N} \mathrm{ha}^{-1} \mathrm{a}^{-1}$, respectively (SE 0.6, 0.9, 2.0, 1.1). Highest annual $\mathrm{N}_{2} \mathrm{O}$ emissions were recorded at site $\mathrm{AR}$ in the third year, whereas site $U G$ released minimum amounts of $\mathrm{N}_{2} \mathrm{O}$ in the second year (Table 2). The high budgets of sites GM and AR showed high variation and thus, did not differ significantly ( $p=0.18$; Fig. 6b).

\subsection{2 $\mathrm{CO}_{2}$ balances and NECB}

For the 2 years of $\mathrm{CO}_{2}$ exchange measurement, mean annual NEE was 2.8, 8.0, 11.7 and $10.1 \mathrm{MgCO}_{2}-\mathrm{Cha}^{-1} \mathrm{a}^{-1}$ for sites UG, GW, GM and AR, respectively (SE 2.5, 0.7, 1.2, 1.9; Fig. 7a). Thus, all sites showed higher annual $R_{\mathrm{ECO}}$ than GPP sums, with highest $R_{\mathrm{ECO}}$ at site AR and lowest $R_{\mathrm{ECO}}$ at site UG, both for the period 2013/14 (Table 2). Highest annual GPP was determined at site AR for 2013/14, whereas site GM showed the lowest GPP during the same period. As for $R_{\mathrm{ECO}}$ and GPP, both highest and lowest NEE occurred in 2013/14 at sites GM and UG, respectively (Table 2). As indicated by NECB, all sites were net $\mathrm{C}$ sources during the study period with mean annual losses of $2.8,10.6,15.7$ and 15.0 $\mathrm{Mg} \mathrm{Cha}^{-1} \mathrm{a}^{-1}$ at sites UG, GW, GM and AR, respectively (SE 2.6, 1.1, 1.4, 2.4; Fig. 7b). Consistent with NEE, a higher range of NECB was assessed for the period 2013/14 with lowest $\mathrm{C}$ losses at site $\mathrm{UG}$ and highest losses at site $\mathrm{AR}$ (Table 2). The NEE and NECB of sites GW and AR did not differ significantly (Fig. 7a and b). However, mean NECB of site AR tended to be higher compared to site GW with $p=0.07$.

\subsubsection{GWP}

The GWP combines the $\mathrm{CO}_{2}-\mathrm{C}$ eq. of NEE, $\mathrm{CH}_{4}$ and $\mathrm{N}_{2} \mathrm{O}$ emissions, as well as the anthropogenic $\mathrm{C}$ balances from slurry applications and biomass removals. For the study periods 2012/13 and 2013/14, mean annual GWP was 3.8, 11.7, 17.7 and $17.3 \mathrm{Mg} \mathrm{CO}_{2}-\mathrm{C}$ eq. ha ${ }^{-1} \mathrm{a}^{-1}$ for sites UG, GW, GM and AR, respectively (SE 2.8, 1.2, 1.8, 2.6; Fig. 7c). The lowest (site UG) as well as the highest GWPs (site AR) were observed for 2013/14 (Table 2). NEE dominated GWP at all sites with mean shares ranging from $59 \%$ at site AR to $72 \%$ at site UG. However, as no biomass removal occurred on site $\mathrm{UG}$, this site also showed the highest shares of $\mathrm{CH}_{4}$ and $\mathrm{N}_{2} \mathrm{O}$, with each gas accounting for $14 \%$ of the GWP based on an average of the 2 years. The GWPs of the agricultural sites were considerably influenced by the $\mathrm{C}$ balances of slurry inputs and harvested biomass, which accounted for 21, 23 and $27 \%$ at sites GW, GM and AR, respectively.

\subsection{Crop yields and yield-related GHG emissions}

\subsubsection{Biomass, carbon, nitrogen and energy yields}

For the grassland sites, all yield parameters were higher in 2012 than in 2013 (Table 3). While this reduction was significant for site GM, site GW showed no significant differences between years. At the arable site, significantly higher yields were obtained by spring wheat with undersown grass in 2013 compared to spring barley in 2012. Site GM revealed significantly higher yields than site AR in 2012, while site GW did not differ from any other site in that year, except for $\mathrm{N}$ yield. In 2013, yields of sites GM and AR showed no significant differences, while site GW had significantly lower yields than the other two sites, except for the $\mathrm{N}$ yield of site AR and the NEL yield of site GM. On average, site GM showed the highest yields, while lowest yields were observed on site GW, except for $\mathrm{N}$ yield, which was lowest on site AR. However, only $\mathrm{N}$ yield of sites GM and AR differed significantly.

\subsubsection{Yield-related GHG emissions}

The annual GWP (Table 2) was related to the annual energy yields (Table 3 ) of the three agricultural study sites. While these yield-related GHG emissions increased for site GM in 


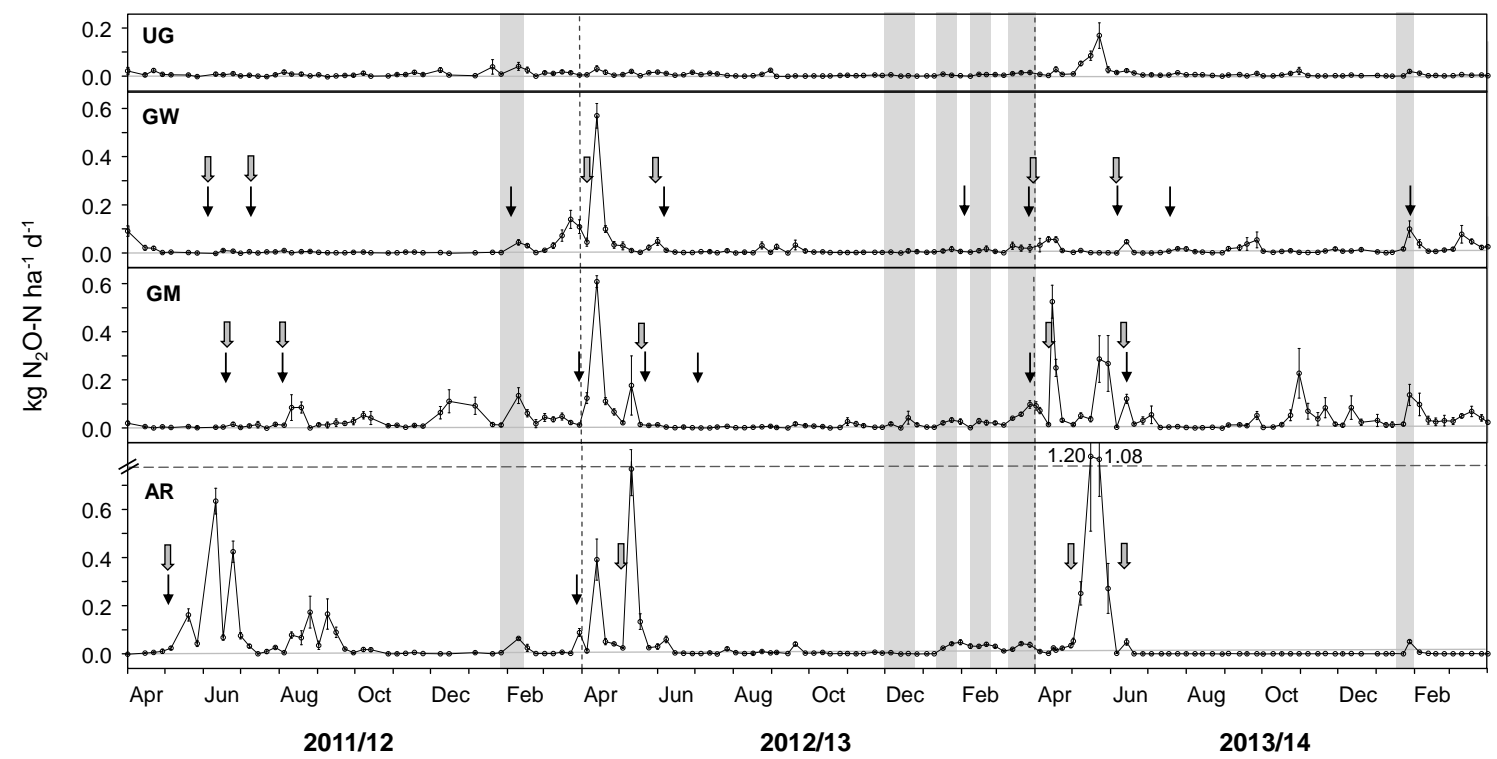

Figure 4. $\mathrm{N}_{2} \mathrm{O}$ exchange at the four study sites during the study period (April 2011-March 2014). Values are displayed as mean \pm standard error $(n=8)$. Note the broken $y$ axis for site AR. Arrows indicate applications of slurry (black) and mineral nitrogen fertilizer (grey). Grey background represents periods with mean daily temperatures below $0{ }^{\circ} \mathrm{C}$.

Table 2. Annual budgets of $\mathrm{CO}_{2}$ exchange ( $R_{\mathrm{ECO}}$, GPP and NEE), $\mathrm{CH}_{4}$ and $\mathrm{N}_{2} \mathrm{O}$ fluxes, net ecosystem carbon balance (NECB) and global warming potential (GWP) for 100 years (IPCC, 2007) for different study periods (each period is April-March). NECB is calculated from $\mathrm{NEE}$ and $\mathrm{CH}_{4}-\mathrm{C}$ as well as slurry $\mathrm{C}$ and harvested $\mathrm{C}$. The GWP includes $\mathrm{CO}_{2}-\mathrm{C}$ eq. of $\mathrm{NEE}, \mathrm{CH}_{4}-\mathrm{C}, \mathrm{N}_{2} \mathrm{O}-\mathrm{N}$, slurry $\mathrm{C}$ and harvested $\mathrm{C}$. Small deviations in NEE are caused by rounding. Values are annual sums and standard errors (in brackets).

\begin{tabular}{|c|c|c|c|c|c|c|c|c|c|c|}
\hline Site & Period & $R_{\mathrm{ECO}}$ & $\begin{array}{r}\mathrm{GPP} \\
\mathrm{g} \mathrm{CO}_{2}-\mathrm{Cha}^{-}\end{array}$ & NEE & $\left(\mathrm{kgCha}^{-1}\right)$ & $\begin{array}{l}\mathrm{CH}_{4} \\
\left(\mathrm{MgCO}_{2}-\mathrm{C} \text { eq. ha }\right. \\
\end{array}$ & $\left(\mathrm{kg} \mathrm{Nha}^{-1}\right)$ & $\begin{array}{l}\mathrm{N}_{2} \mathrm{O} \\
\left(\mathrm{MgCO}_{2}-\mathrm{C} \text { eq. ha }{ }^{-1}\right)\end{array}$ & $\begin{array}{r}\text { NECB } \\
\left(\mathrm{MgCha}^{-1}\right)\end{array}$ & $\begin{array}{r}\text { GWP } \\
\left(\mathrm{Mg} \mathrm{CO}_{2}-\mathrm{C} \text { eq. ha }\right. \\
\end{array}$ \\
\hline \multirow[t]{3}{*}{$\mathrm{UG}$} & $2011 / 12$ & - & - & - & $38.6(10.6)$ & $0.35(0.10)$ & $3.3(1.2)$ & $0.43(0.15)$ & - & - \\
\hline & $2012 / 13$ & $20.7(2.3)$ & $-16.8(3.1)$ & $3.9(3.8)$ & $99.5(47.8)$ & $0.91(0.44)$ & $2.3(0.4)$ & $0.29(0.05)$ & $4.0(3.9)$ & $5.1(4.3)$ \\
\hline & $2013 / 14$ & $17.9(0.8)$ & $-16.3(0.9)$ & $1.7(1.2)$ & $27.0(9.7)$ & $0.25(0.09)$ & $4.5(1.1)$ & $0.57(0.13)$ & $1.7(1.2)$ & $2.5(1.3)$ \\
\hline \multirow[t]{3}{*}{ GW } & $2011 / 12$ & - & - & - & $6.6(1.7)$ & $0.06(0.02)$ & $4.7(1.1)$ & $0.59(0.14)$ & - & - \\
\hline & $2012 / 13$ & $26.6(0.2)$ & $-17.5(0.3)$ & $9.1(0.4)$ & $16.5(2.8)$ & $0.15(0.03)$ & $8.9(2.0)$ & $1.14(0.26)$ & $13.0(1.0)$ & $14.3(1.2)$ \\
\hline & $2013 / 14$ & $24.7(0.8)$ & $-17.8(0.5)$ & $6.9(0.9)$ & $17.3(11.7)$ & $0.16(0.11)$ & $5.9(1.0)$ & $0.76(0.13)$ & $8.3(1.1)$ & $9.2(1.3)$ \\
\hline \multirow[t]{3}{*}{ GM } & $2011 / 12$ & - & - & - & $1.1(0.6)$ & $0.01(0.01)$ & $11.4(3.0)$ & $1.45(0.38)$ & - & - \\
\hline & $2012 / 13$ & $29.6(1.1)$ & $-18.3(0.4)$ & $11.4(1.1)$ & $1.5(0.8)$ & $0.01(0.01)$ & $12.5(1.9)$ & $1.59(0.24)$ & $15.7(1.3)$ & $17.3(1.5)$ \\
\hline & $2013 / 14$ & $24.9(1.2)$ & $-13.0(0.4)$ & $12.0(1.3)$ & $0.2(0.9)$ & $0.001(0.01)$ & $19.3(4.7)$ & $2.46(0.60)$ & $15.7(1.5)$ & $18.2(2.9)$ \\
\hline \multirow[t]{3}{*}{$\mathrm{AR}$} & $2011 / 12$ & - & - & - & $0.8(1.8)$ & $0.01(0.02)$ & $20.0(1.8)$ & $2.55(0.26)$ & - & - \\
\hline & $2012 / 13$ & $24.7(1.3)$ & $-15.7(0.9)$ & $9.0(1.5)$ & $4.5(0.7)$ & $0.04(0.01)$ & $15.3(1.4)$ & $1.95(0.17)$ & $12.2(1.8)$ & $14.2(1.9)$ \\
\hline & $2013 / 14$ & $33.3(2.2)$ & $-22.1(0.7)$ & $11.2(2.3)$ & $0.2(0.3)$ & $0.002(0.003)$ & $21.6(2.1)$ & $2.76(0.27)$ & $17.7(3.0)$ & $20.5(3.3)$ \\
\hline
\end{tabular}

the second year, they decreased for sites GW and AR (Table 4). Based on an average of the 2-year study period, site GM did not differ significantly from the other sites, whereas site GW showed significantly lower yield-related emissions than site AR.

\section{Discussion}

\section{1 $\mathrm{CH}_{4}$ fluxes and balances}

Sites GM and AR showed negligible $\mathrm{CH}_{4}$ fluxes, and annual $\mathrm{CH}_{4}$ budgets were not significantly different from zero. This is in accordance with other observations on intensively used peat soils that report low $\mathrm{CH}_{4}$ emissions or even net uptake of $\mathrm{CH}_{4}$ (Flessa et al., 1998; Maljanen et al., 2003a, 2004; Schäfer et al., 2012). The water table is the main controlling factor for $\mathrm{CH}_{4}$ emissions from peat soils, particularly in absence of aerenchyma shunt species. A drainage depth of $20-30 \mathrm{~cm}$ is regarded as sufficient to inhibit the diffusion of high amounts of $\mathrm{CH}_{4}$ into the atmosphere as $\mathrm{CH}_{4}$ produced in the anoxic zone is oxidized by methanotrophs in the unsaturated zone (Couwenberg, 2009a; Schäfer et al., 2012). Accordingly, the low $\mathrm{CH}_{4}$ fluxes at sites GM and AR can be explained by the high drainage intensity. However, a high GWL close to or above the soil surface did not enhance $\mathrm{CH}_{4}$ production and emission at these sites (Fig. 8). A multiple 


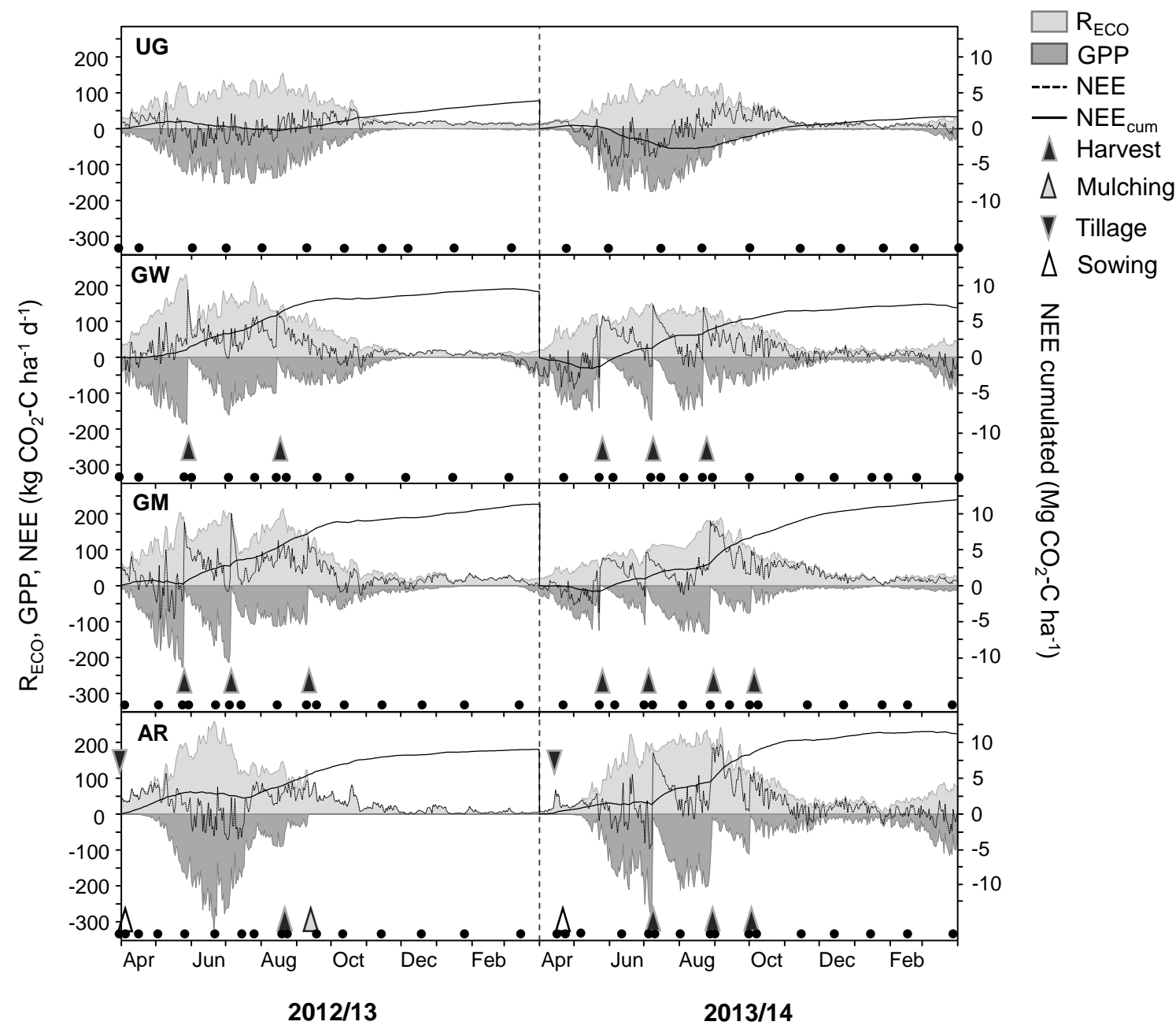

Figure 5. $\mathrm{CO}_{2}$ exchange at the four study sites during a 2-year study period (April 2012-March 2014). Values are displayed as daily means of the model output $(n=3)$. The black continuous line shows the cumulated NEE for 1 year. The black dots represent $\mathrm{CO}_{2}$ measurement campaigns.

Table 3. Annual yields of dry matter (DM), carbon (C), nitrogen (N) and net energy lactation (NEL) for the three agricultural utilized study sites and 2 years. Different capital letters indicate significant differences between the sites for a particular year. Different lowercase letters indicate significant differences between the years for a particular site $(p<0.05)$. Values in brackets are standard errors $(n=3)$. Crops at site AR were summer barley (2012) and summer wheat with undersown grass (2013).

\begin{tabular}{lrrr|rr|rr|rr}
\hline Site & Year & \multicolumn{2}{c|}{$\begin{array}{c}\mathrm{DM} \\
\left(\mathrm{Mg} \mathrm{ha}^{-1} \mathrm{a}^{-1}\right)\end{array}$} & $\begin{array}{c}\mathrm{C} \\
\left(\mathrm{Mg} \mathrm{ha}^{-1} \mathrm{a}^{-1}\right)\end{array}$ & $\begin{array}{c}\mathrm{N} \\
\left(\mathrm{kg} \mathrm{ha}^{-1} \mathrm{a}^{-1}\right)\end{array}$ & $\begin{array}{c}\text { NEL } \\
\left(\mathrm{GJ} \mathrm{ha}^{-1} \mathrm{a}^{-1}\right)\end{array}$ \\
\hline GW & 2012 & $10.7(1.2)$ & $\mathrm{ABa}$ & $4.9(0.6)$ & $\mathrm{ABa}$ & $234(31)$ & $\mathrm{Ba}$ & $63.9(7.0)$ & $\mathrm{ABa}$ \\
& 2013 & $8.2(0.4)$ & $\mathrm{Aa}$ & $3.7(0.2)$ & $\mathrm{Aa}$ & $218(8)$ & $\mathrm{Aa}$ & $53.6(3.2)$ & $\mathrm{Aa}$ \\
& Mean & $9.5(0.8)$ & $\mathrm{A}$ & $4.3(0.4)$ & $\mathrm{A}$ & $226(15)$ & $\mathrm{AB}$ & $58.7(3.9)$ & $\mathrm{A}$ \\
\hline $\mathrm{GM}$ & 2012 & $13.1(0.3)$ & $\mathrm{Bb}$ & $5.9(0.2)$ & $\mathrm{Bb}$ & $335(7)$ & $\mathrm{Cb}$ & $78.8(1.7)$ & $\mathrm{Bb}$ \\
& 2013 & $10.0(0.4)$ & $\mathrm{Ba}$ & $4.5(0.2)$ & $\mathrm{Ba}$ & $274(17)$ & $\mathrm{Ba}$ & $66.1(3.0)$ & $\mathrm{ABa}$ \\
& Mean & $11.5(0.6)$ & $\mathrm{A}$ & $5.2(0.3)$ & $\mathrm{A}$ & $305(13)$ & $\mathrm{B}$ & $72.5(2.7)$ & $\mathrm{A}$ \\
\hline AR & 2012 & $8.2(0.5)$ & $\mathrm{Aa}$ & $3.7(0.2)$ & $\mathrm{Aa}$ & $107(11)$ & $\mathrm{Aa}$ & $47.5(2.6)$ & $\mathrm{Aa}$ \\
& 2013 & $14.6(1.6)$ & $\mathrm{Bb}$ & $6.5(0.7)$ & $\mathrm{Bb}$ & $296(34)$ & $\mathrm{ABb}$ & $88.1(8.2)$ & $\mathrm{Bb}$ \\
& Mean & $11.4(1.3)$ & $\mathrm{A}$ & $5.1(0.6)$ & $\mathrm{A}$ & $202(38)$ & $\mathrm{A}$ & $67.8(8.2)$ & $\mathrm{A}$ \\
\hline
\end{tabular}




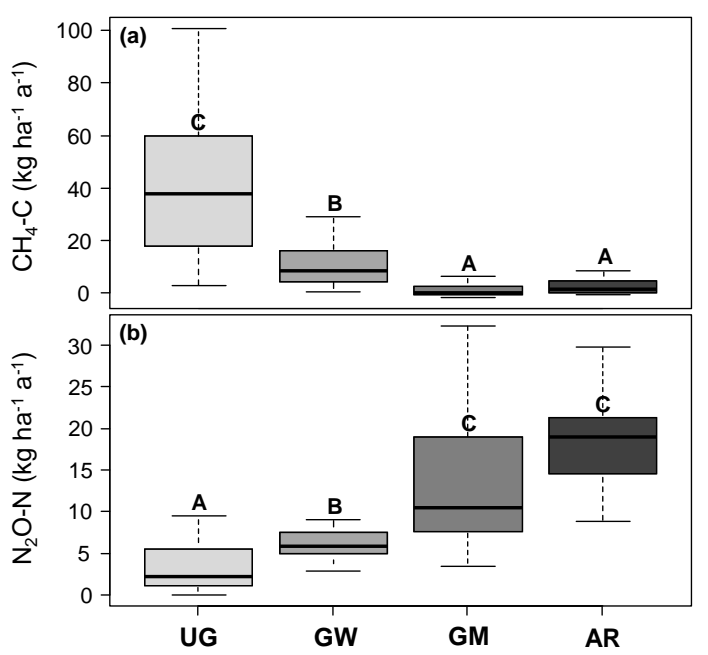

Figure 6. Annual emissions of $\mathrm{CH}_{4}$ (a) and $\mathrm{N}_{2} \mathrm{O}$ (b) at the four study sites combined for 3 years (April 2011-March 2014) of measurement $(n=24)$. Different capital letters indicate significant differences between the sites $(p<0.05)$.

Table 4. Annual GHG balances $\left(\mathrm{CO}_{2}, \mathrm{CH}_{4}\right.$ and $\mathrm{N}_{2} \mathrm{O}$ fluxes, slurry $\mathrm{C}$ and harvested $\mathrm{C}$ ) of the three agricultural study sites in relation to energy yield (net energy lactation, NEL). Different capital letters indicate significant differences between the sites $(p<0.05)$. Values in brackets are standard errors $(n=3)$.

\begin{tabular}{|c|c|c|c|c|c|c|}
\hline \multirow{4}{*}{$\begin{array}{l}\text { Period } \\
2012 / 13\end{array}$} & \multicolumn{6}{|c|}{ Site } \\
\hline & \multirow[t]{2}{*}{ GW } & & \multicolumn{2}{|c|}{ GM } & \multicolumn{2}{|l|}{ AR } \\
\hline & & \multicolumn{5}{|c|}{$\mathrm{kg} \mathrm{CO}_{2}-\mathrm{C}$ eq. (GJ NEL) ${ }^{-1}$} \\
\hline & $231(25)$ & & $220(5)$ & & $301(18)$ & \\
\hline $2013 / 14$ & $172(10)$ & & $276(12)$ & & $236(21)$ & \\
\hline Mean & $201(17)$ & A & $248(9)$ & $\mathrm{AB}$ & 269 (19) & B \\
\hline
\end{tabular}

linear regression model showed significant relations between log-transformed daily $\mathrm{CH}_{4}$ fluxes and site $(p<0.001)$, GWL $(p<0.001)$ and soil temperature at $5 \mathrm{~cm}$ depth $(p<0.01)$. However, the model only explained $11 \%$ of the variation in the $\mathrm{CH}_{4}$ flux data (Nakagawa and Schielzeth, 2013) indicating the high complexity of $\mathrm{CH}_{4}$ emission patterns and its relations to driver variables. Also, reactions on alterations of GWL and soil temperature differed between sites, probably as a consequence of long-term adaptation of methanogenic and methanotrophic communities to drainage intensity (van den Pol-van Dasselaar et al., 1997; Yrjälä et al., 2011). At site $\mathrm{GW}, \mathrm{CH}_{4}$ production potential was higher compared to sites GM and $\mathrm{AR}$, leading to considerable $\mathrm{CH}_{4}$ releases, especially when GWL and soil temperature were high, for example, as in summer 2012 (Fig. 3).

Conspicuous $\mathrm{CH}_{4}$ peaks were detected at site UG in 2012 (Figs. 3 and 8) that were associated with high GWLs due to heavy rain fall in July and high soil temperatures due to a heat wave in late July and August (Figs. 1 and 2). These con-
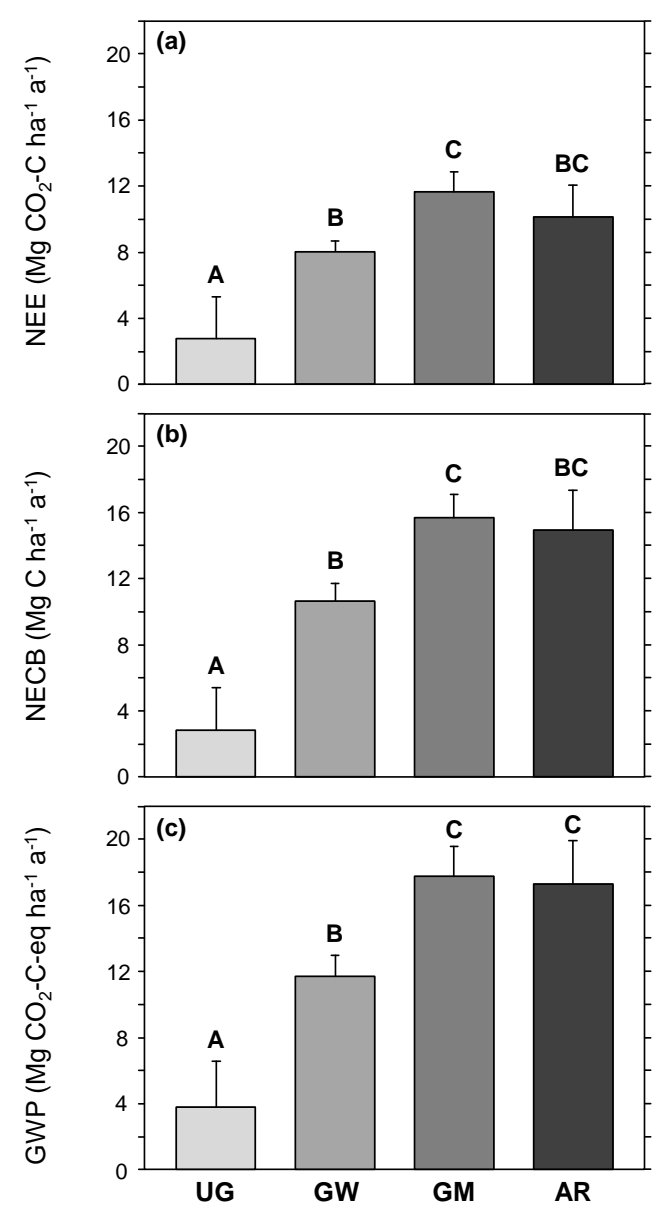

Figure 7. Mean annual budgets of net ecosystem exchange (NEE) of $\mathrm{CO}_{2}$ (a), net ecosystem carbon balance (NECB; b) and global warming potential (GWP; $\mathbf{c}$ ) at the four study sites for the period April 2012-March $2014(n=6)$. Error bars represent standard error. Different capital letters indicate significant differences between the sites $(p<0.05)$.

ditions likely favored a rapid expansion of the methanogenic community, more pronounced than in summer 2011 when GWLs were similarly high but temperatures were lower. Nykänen et al. (1998) reported that peat temperature controls $\mathrm{CH}_{4}$ dynamics at high water tables, whereas the correlation is poor at low water tables. This is confirmed by the situation at site UG in summer 2013 when $\mathrm{CH}_{4}$ emissions ceased as a consequence of low precipitation and water level drawdown in July and August, although soil temperatures were high. The subsequent GWL rise in autumn had no effect on $\mathrm{CH}_{4}$ emissions, which remained low until the end of the study period. A possible explanation is that the methanogenic community was impaired by oxidative stress in summer (Görres et al., 2013) and did not recover due to low soil temperature when GWL rose (Bubier and Moore, 1994). Knorr et al. (2008) reported that $\mathrm{CH}_{4}$ production in a fen soil was retarded by experimental drought for up to several weeks af- 


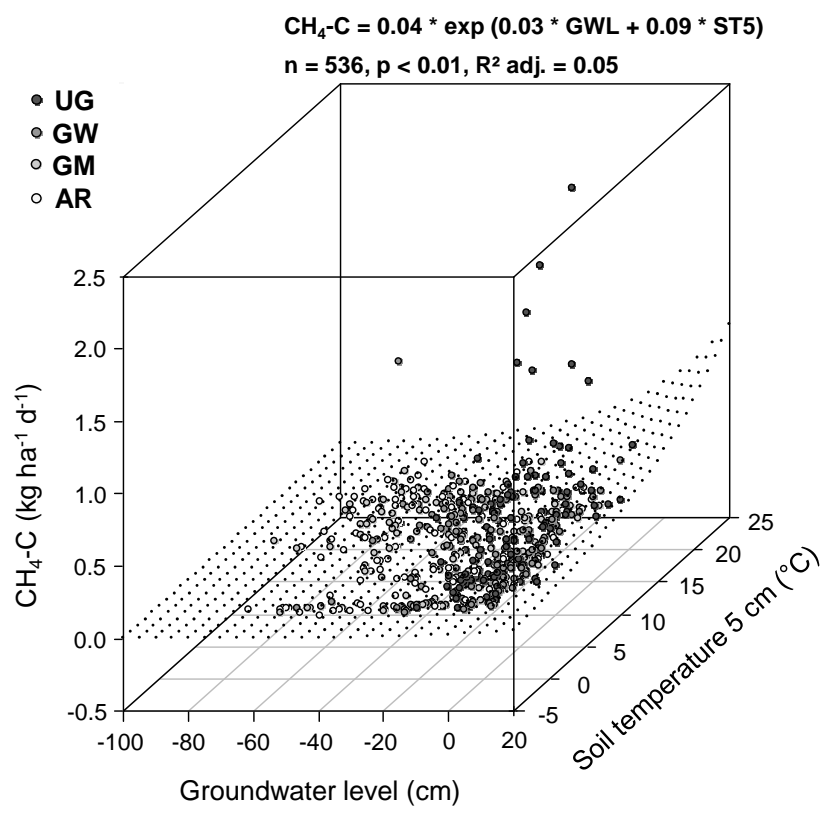

Figure 8. Relationship of daily $\mathrm{CH}_{4}$ fluxes to groundwater level and mean daily soil temperature at $5 \mathrm{~cm}$ depth. GWL in the equation is groundwater level $(\mathrm{cm})$ and ST5 is soil temperature at $5 \mathrm{~cm}$ depth $\left({ }^{\circ} \mathrm{C}\right) . R^{2}$ adjusted was estimated for predicted vs. obtained values.

ter rewetting. Estop-Aragonés and Blodau (2012) observed a longer time lag until $\mathrm{CH}_{4}$ production recovered after rewetting for more intense and longer dried fen peat but warmer conditions favored the recovery. Furthermore, the dry soil conditions in summer 2013 could have increased the methanotrophic community, leading to a $\mathrm{CH}_{4}$ consumption potential in the subsequent months exceeding the production potential as methanotrophic bacteria react less sensitively to temperature changes than methanogenic bacteria (Dunfield et al., 1993). This is supported by the results of this study as the overall highest daily $\mathrm{CH}_{4}$ uptakes were measured at site UG in summer and autumn 2013.

Annual $\mathrm{CH}_{4}$ balances of the study sites are comparable to those recently reported for temperate European peat soils (Schäfer et al., 2012; Beetz et al., 2013; Leiber-Sauheitl et al., 2014). Annual balances were significantly related to site and mean annual GWL (both with $p<0.001$ ). Confirming the general understanding of $\mathrm{CH}_{4}$ emission patterns (Couwenberg, 2009a), no significant $\mathrm{CH}_{4}$ releases were observed for mean GWLs below $-25 \mathrm{~cm}$. At mean GWLs above $-10 \mathrm{~cm}$, $\mathrm{CH}_{4}$ emissions were highly variable, with a minimum release of 28 and a maximum of $430 \mathrm{~kg} \mathrm{CH}_{4}-\mathrm{Cha}^{-1} \mathrm{a}^{-1}$ (Fig. 10a), which is typical for the high spatial variability of $\mathrm{CH}_{4}$ fluxes (Waddington and Roulet, 1996; van den Pol-van Dasselaar et al., 1999). The low contribution of $\mathrm{CH}_{4}$ emissions to the GWP of the three agricultural sites (Table 2) illustrates the minor importance of $\mathrm{CH}_{4}$ in terms of GHG mitigation on utilized peat soils. However, Hahn-Schöfl et al. (2011) showed that degraded fen grasslands can emit huge amounts of $\mathrm{CH}_{4}$

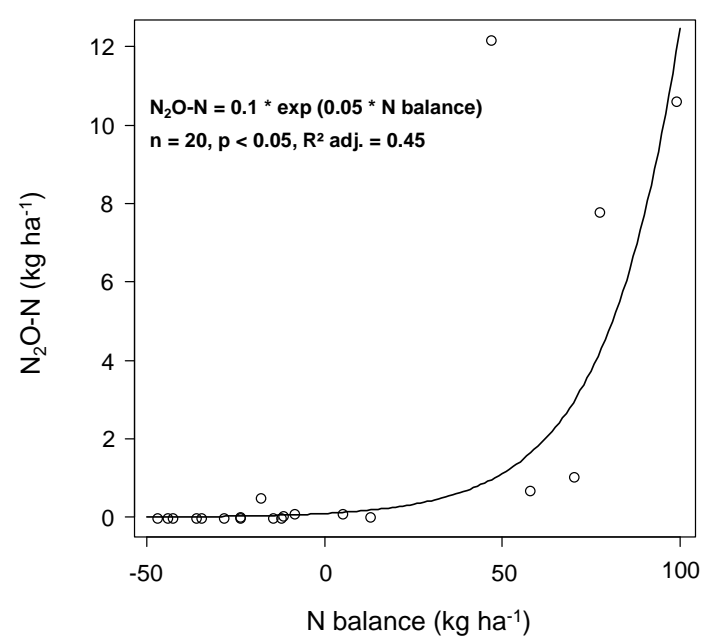

Figure 9. Relationship of cumulated $\mathrm{N}_{2} \mathrm{O}$ fluxes $(n=8)$ for a certain period of the growing seasons 2012 and 2013 at the arable site (AR) to nitrogen balance $(n=3)$ for the same period, calculated from mineral $\mathrm{N}$ input of mineral and organic fertilizers and the $\mathrm{N}$ removal by plants. $R^{2}$ adjusted was estimated for predicted vs. obtained values.

as a consequence of flooding when easily degradable fresh plant material is present. Therefore, inundation of sites with highly productive, energy-rich grasses such as perennial ryegrass (Lolium perenne) bears the risk of enhanced $\mathrm{CH}_{4}$ emissions, especially during summer. This should be particularly considered for site $\mathrm{GW}$, where a significant $\mathrm{CH}_{4}$ production potential could be observed.

\section{$4.2 \quad \mathrm{~N}_{2} \mathrm{O}$ fluxes and balances}

$\mathrm{N}_{2} \mathrm{O}$ emissions measured at the study sites were of similar magnitude as observed for other agricultural fen soils, for example, in southern Germany (Flessa et al., 1998), the Netherlands (van Beek et al., 2010, 2011) or Denmark (Petersen et al., 2012) and conform to the range of $\mathrm{N}_{2} \mathrm{O}$ hotspots on European organic soils given by Leppelt et al. (2014). The $\mathrm{N}_{2} \mathrm{O}$ release from site UG represents the emissions without agricultural utilization in the study area. These were higher than reported for natural peatlands (Leppelt et al., 2014), which might be a result of GWL fluctuations (Figs. 2 and 10b), as background $\mathrm{N}_{2} \mathrm{O}$ emissions strongly depend on drainage intensity (van Beek et al., 2011). A multiple linear regression model for log-transformed daily $\mathrm{N}_{2} \mathrm{O}$ fluxes gave significant effects of site and the amount of nitrate in $0-20 \mathrm{~cm}$ soil depth (both with $p<0.001$ ) with highest fluxes measured at high soil nitrate. By this model, $64 \%$ of the variation of measured $\mathrm{N}_{2} \mathrm{O}$ fluxes could be explained (Nakagawa and Schielzeth, 2013).

Soil nitrate contents are enhanced by mineral fertilizer inputs, as well as by mineralization and nitrification of organic $\mathrm{N}$ in soil organic matter (SOM) or organic fertilizers. Several $\mathrm{N}_{2} \mathrm{O}$ emission peaks at the three agricultural study sites 


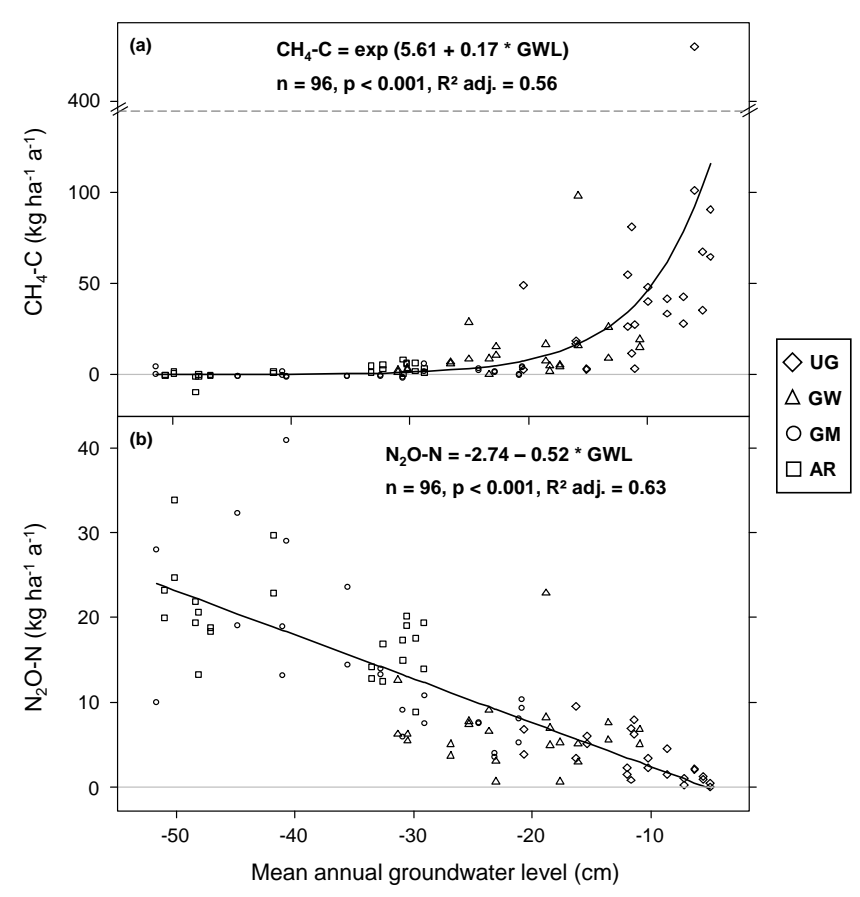

Figure 10. Relationships of cumulated annual $\mathrm{CH}_{4}$ (a) and $\mathrm{N}_{2} \mathrm{O}$ fluxes (b) to mean annual groundwater level for the study period (April 2011-March 2014) with $n=8$ per site and year. GWL in the equations is the mean annual groundwater level $(\mathrm{cm}) . R^{2}$ adjusted for exponential regression (a) was estimated for predicted vs. obtained values. Note the broken $y$ axis for figure (a).

occurred subsequent to mineral fertilizer or slurry application, especially at site AR and in spring 2012 at all three sites (Fig. 4). High soil nitrate, exceeding the current $\mathrm{N}$ uptake capacity of vegetation can cause increased $\mathrm{N}_{2} \mathrm{O}$ production through denitrification; thus, $\mathrm{N}$ fertilization often leads to enhanced $\mathrm{N}_{2} \mathrm{O}$ emissions for several days to weeks (Velthof and Oenema, 1995b; Bouwman et al., 2002; Grant et al., 2006). In addition, a nitrate surplus in soil promotes incomplete denitrification and increasing $\mathrm{N}_{2} \mathrm{O} / \mathrm{N}_{2}$ product ratios with the associated risk of $\mathrm{N}_{2} \mathrm{O}$ emissions (Firestone et al., 1980; Farquharson and Baldock, 2008; Senbayram et al., 2012). At site AR, strong $\mathrm{N}_{2} \mathrm{O}$ emission peaks occurred after fertilization in spring when vegetation was missing or seeded plants were emerging (Fig. 4).

Therefore, instead of relating annual $\mathrm{N}_{2} \mathrm{O}$ emissions to annual $\mathrm{N}$ balances, short-term $\mathrm{N}$ balances for about 2-week intervals were calculated for site $\mathrm{AR}$ and the vegetation periods 2012 and 2013 and related to the $\mathrm{N}_{2} \mathrm{O}$ balances of the same period. This was conducted by considering the $\mathrm{N}$ input by fertilizers as well as the $\mathrm{N}$ uptake by plants (Fig. 9). During the first weeks after fertilizer application, $\mathrm{N}$ surpluses of up to $99 \mathrm{~kg} \mathrm{ha}^{-1}$ occurred, leading to extremely high short-term $\mathrm{N}_{2} \mathrm{O}$ releases in some cases. The increasing $\mathrm{N}$ uptake in the subsequent periods was characterized by $\mathrm{N}$ balances ranging from -48 to $12 \mathrm{~kg} \mathrm{~N} \mathrm{ha}^{-1}$ without significant $\mathrm{N}_{2} \mathrm{O}$ emis- sions. These findings confirm a meta-analysis of van Groenigen et al. (2010), who found no differences in $\mathrm{N}_{2} \mathrm{O}$ emissions for negative or slightly positive $\mathrm{N}$ balances, but significantly increasing emissions for a surplus of $90 \mathrm{~kg} \mathrm{Nha}^{-1}$. During the period $2012 / 13,73 \%$ of $\mathrm{N}_{2} \mathrm{O}$ emissions at site AR occurred in April and May, while for the period 2013/14, $90 \%$ of the total annual $\mathrm{N}_{2} \mathrm{O}$ budget was emitted in May. Therefore, it can be concluded that in combination with tilling, which might increase the availability of easily decomposable organic C for denitrifiers (Nykänen et al., 1995), fertilization of peat soils during periods with lacking $\mathrm{N}$ uptake capacity, bears the risk of substantial $\mathrm{N}_{2} \mathrm{O}$ emissions (Maljanen et al., 2003b; Regina et al., 2004).

After a second smaller fertilization peak at site AR in June $2013, \mathrm{~N}_{2} \mathrm{O}$ emissions were reduced to zero or even small uptakes of $\mathrm{N}_{2} \mathrm{O}$ were detected (Fig. 4), which can be explained by increased vegetation productivity. The growing plants act as competitors for nitrate to the denitrifiers, leading them to complete denitrification as nitrate availability is strongly decreased. This was described for pristine (Roobroeck et al., 2009) or restored peatlands (Silvan et al., 2005) were N availability is usually limited (Martikainen et al., 1993). Our results suggest that on sites with very high $\mathrm{N}_{2} \mathrm{O}$ production potential, emissions can be eliminated by a continuous coverage of highly productive plants and prevention of fertilization when $\mathrm{N}$ uptake is limited. $\mathrm{N}_{2} \mathrm{O}$ uptake into soils is often linked to low mineral $\mathrm{N}$ and high moisture contents (Chapuis-Lardy et al., 2007). However, the small but continuous $\mathrm{N}_{2} \mathrm{O}$ uptakes at site AR, beginning in June 2013, were probably attributed to a high denitrification potential, stimulated by the excess of nitrate during May and shifted to $\mathrm{N}_{2} \mathrm{O}$ consumption by denitrifiers when nitrate competition by plant roots increased (Roobroeck et al., 2009).

On average, $\mathrm{N}_{2} \mathrm{O}-\mathrm{N}$ emissions from the agricultural study sites accounted for 2.2, 5.9 and $13.2 \%$ of applied $\mathrm{N}$ for sites $\mathrm{GW}, \mathrm{GM}$ and AR, respectively. The values for sites GW and GM fit well with those presented by van Beek et al. (2010) for grazed grasslands on organic soil in the Netherlands with comparable GWLs. Therefore, our results support the findings of van Beek et al. (2010), who argued that mean annual GWL should be used in addition to $\mathrm{N}$ input for estimating $\mathrm{N}_{2} \mathrm{O}$ emissions from organic soils, as the ratio of $\mathrm{N}_{2} \mathrm{O}$ emissions to $\mathrm{N}$ input increases with decreasing GWLs. However, our results illustrate that the type of management should be considered as well, as arable cropping can induce a disproportional increase of $\mathrm{N}_{2} \mathrm{O}$ emissions related to $\mathrm{N}$ input.

Drained organic soils are known to emit significant shares of their annual $\mathrm{N}_{2} \mathrm{O}$ budget during the winter period (Priemé and Christensen, 2001; Maljanen et al., 2003b), increasing with the number of freezing and thawing cycles (Regina et al., 2004). Thereby, $\mathrm{N}_{2} \mathrm{O}$ emissions can be enhanced during freezing as well as thawing, since both processes release $\mathrm{C}$ into the soil, which is rapidly utilized by heterotrophic denitrifiers (Koponen et al., 2006). In the present study, $\mathrm{N}_{2} \mathrm{O}$ pulses occurred during freezing events but fluxes declined 
rapidly after freezing. This was more pronounced when no snow cover was present as observed in the first and third winter when only one period with negative temperatures occurred, but not in the second winter, when more freezing and thawing cycles appeared (Figs. 1 and 4 ). These results suggest that the predominating process that enhanced winter $\mathrm{N}_{2} \mathrm{O}$ fluxes was freezing rather than thawing of the peat soils. As wet peat soils have a high heat capacity, $\mathrm{N}_{2} \mathrm{O}$ fluxes did not increase directly after air temperatures became negative but a few days later due to the time lag between changes in air and soil temperature. This could also explain the missing $\mathrm{N}_{2} \mathrm{O}$ pulse in the second winter as the frost could not penetrate the peat sufficiently to generate an enhanced release of $\mathrm{C}$ and $\mathrm{N}$ as a consequence of the snow cover. Xu et al. (2016) demonstrated that the release of $\mathrm{C}$ and $\mathrm{N}$ during freezing as well as $\mathrm{N}_{2} \mathrm{O}$ emissions were enhanced by a lower freezing temperature, which underlines the results of this study.

Annual $\mathrm{N}_{2} \mathrm{O}$ emissions were significantly related to mean annual GWL (Fig. 10b), which might be explained by increasing amounts of nitrate in top soil with increasing drainage intensity (Fig. 11a). As the differences in soil nitrate could not be attributed to different $\mathrm{N}$ fertilization intensities (Table 1), the GWL seemed to control nitrification processes. Koops et al. (1997) emphasized that nitrification is an important process for $\mathrm{N}_{2} \mathrm{O}$ losses from peat soils, while Dowrick et al. (1999) stated that denitrification is the main source for $\mathrm{N}_{2} \mathrm{O}$ emissions from drained organic soils as the nitrate produced from peat mineralization is reduced in small-scale anaerobic porosity. However, both nitrification and denitrification processes likely contributed to $\mathrm{N}_{2} \mathrm{O}$ emissions as sites GM and AR showed strong fluctuations in GWL (Fig. 2), which generally leads to a pronounced cycling of both processes and thus enhanced $\mathrm{N}_{2} \mathrm{O}$ release (Goldberg et al., 2010; Jørgensen and Elberling, 2012).

\section{$4.3 \mathrm{CO}_{2}$ exchange and $\mathrm{NECB}$}

All four study sites were net $\mathrm{C}$ sources during the 2 years of $\mathrm{CO}_{2}$ measurements (Table 2 and Fig. 7). Compared to IPCC (2014) emission factors for temperate organic soils, the sites showed NEE values above the given range for their respective land use categories. While the NEE of site AR was $9.0 \mathrm{MgCO}_{2}-\mathrm{Cha}^{-1} \mathrm{a}^{-1}$ in $2012 / 13$, which is within the $95 \%$ confidence interval of $6.5-9.4 \mathrm{MgCO}_{2}-$ $\mathrm{Cha}^{-1} \mathrm{a}^{-1}$ given by IPCC (2014) for drained temperate croplands, it was above that range in $2013 / 14\left(11.2 \mathrm{Mg} \mathrm{CO}_{2}-\right.$ $\mathrm{Cha}^{-1} \mathrm{a}^{-1}$ ). The NEE of sites GM and GW exceeded the intervals for nutrient-rich temperate grasslands that are deep drained (5.0-7.3 $\mathrm{Mg} \mathrm{CO}_{2}-\mathrm{Cha}^{-1} \mathrm{a}^{-1}$ ) or shallow drained (1.8-5.4 $\mathrm{Mg} \mathrm{CO}_{2}-\mathrm{Cha}^{-1} \mathrm{a}^{-1}$ ) in both years (Table 2). If the NECB is considered, the $\mathrm{C}$ losses of the agricultural sites were even higher, thus exceeding the upper values of IPCC emission factors for the respective land use categories by a factor of 2.0, 2.2 and 1.6 for sites GW, GM and AR, respectively. Moreover, the $\mathrm{C}$ loss from site UG clearly exceeded the average IPCC emission factor for rewetted and nutrientrich temperate organic soils of $0.5 \mathrm{MgCO}_{2}-\mathrm{Cha}^{-1} \mathrm{a}^{-1}$ in both years.

Recently published results for utilized organic soils in the same climatic region as the study area of this observation showed net $\mathrm{C}$ losses of $4.3-8.2 \mathrm{Mg} \mathrm{CO}_{2}-\mathrm{Cha}^{-1} \mathrm{a}^{-1}$ for an intensively managed peat bog grassland in Germany (Beetz et al., 2013), 3.3-8.6 $\mathrm{Mg} \mathrm{CO}_{2}-\mathrm{C} \mathrm{ha}^{-1} \mathrm{a}^{-1}$ for extensively managed grasslands on histic Gleysol in Germany (Leiber-Sauheitl et al., 2014) and 6.9-16.7 $\mathrm{Mg} \mathrm{CO}_{2-}$ $\mathrm{C} \mathrm{ha}^{-1} \mathrm{a}^{-1}$ for grassland and arable cropping on bog and fen soils in Denmark (Elsgaard et al., 2012). The highest value of 16.7 $\mathrm{MgCO}_{2}-\mathrm{Cha}^{-1} \mathrm{a}^{-1}$ represented a rotational grassland on fen soil, thus a comparable system to site AR in 2013/14, which showed a similar NECB of $17.7 \mathrm{MgCO}_{2}-\mathrm{Cha}^{-1} \mathrm{a}^{-1}$. However, the NEE of the Danish site was even higher $\left(13.6 \mathrm{MgCO}_{2}-\mathrm{Cha}^{-1} \mathrm{a}^{-1}\right)$ than at site AR $\left(11.2 \mathrm{Mg} \mathrm{CO}_{2}-\right.$ $\mathrm{C} \mathrm{ha}^{-1} \mathrm{a}^{-1}$ ), indicating that $\mathrm{C}$ removal by harvest from site AR was comparatively high. The permanent grassland sites studied by Elsgaard et al. (2012) showed C losses between 6.9 and $10.4 \mathrm{Mg} \mathrm{CO}_{2}-\mathrm{Cha}^{-1} \mathrm{a}^{-1}$. In conclusion, $\mathrm{C}$ losses of sites UG, GW and AR were at the upper end of literature values, while the NECB of site GM clearly exceeded the given ranges. The comparatively high $\mathrm{C}$ losses of the study sites highlight the functioning of the study region as a considerable $\mathrm{C}$ source, underlining the need for mitigation strategies.

Seasonal variability of NEE on agricultural grasslands cannot only be explained by environmental parameters as their influence is often superposed by management activities like grassland cuttings (Wohlfahrt et al., 2008b). Land use intensity affects the NEE of ecosystems, as the frequency of biomass removals influences respiration processes as well as photosynthesis (Soussana et al., 2007). Generally, it is assumed that NEE increases with the number of cuttings, since GPP is reduced to almost zero for several days after harvest, while $R_{\mathrm{ECO}}$ can remain high, depending on the extent of soil respiration (Schmitt et al., 2010). At the studied grassland sites, $R_{\mathrm{ECO}}$ was often reduced by cutting events but not in the same degree as GPP, leading to sharp increases of NEE after harvest (Fig. 5). The effect of an increased number of grassland cuttings was especially pronounced at site GM, where four cuttings were conducted in the second year, compared to three cuttings in the first year. Thereby, GPP was reduced to a greater extent than $R_{\mathrm{ECO}}$, leading to a slightly increased NEE. However, at site GW the effect was different when the number of cuttings increased from two in the first to three in the second year. Here, a smaller $R_{\mathrm{ECO}}$ but slightly increased GPP resulted in a lower NEE in the second year. The same effect was visible for GPP when comparing sites GM and GW for a given year (Table 2). These results suggest that changing grassland management from two to three cuttings per year did not reduce total annual photosynthetic activity, while GPP could be diminished by four cuttings. However, irrespective of total number of grassland harvests, the first cuts were performed in May, the common time for in- 


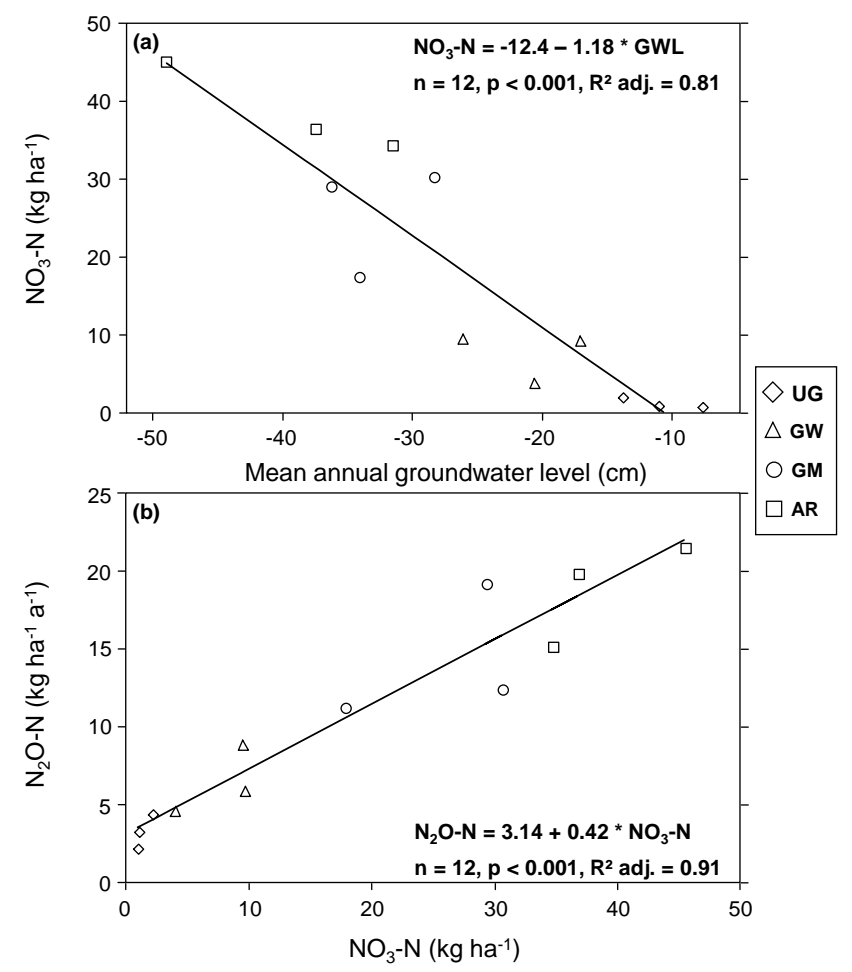

Figure 11. Relationship of mean annual amount of nitrate in 0 $20 \mathrm{~cm}$ soil depth to mean annual groundwater level (a) and relationship of mean annual $\mathrm{N}_{2} \mathrm{O}$ balances to mean annual amount of nitrate in $0-20 \mathrm{~cm}$ soil depth (b). GWL in the equation (a) is the mean annual groundwater level $(\mathrm{cm}), \mathrm{NO}_{3}-\mathrm{N}$ in $(\mathbf{b})$ is the mean annual amount of nitrate in $0-20 \mathrm{~cm}\left(\mathrm{~kg} \mathrm{~N} \mathrm{ha}^{-1}\right)$.

tensively managed grasslands as the average growth rate is at its maximum (Parsons and Chapman, 2000). Before the first cut, the NEE of grasslands is mainly controlled by GPP (Wohlfahrt et al., 2008a). Shifting the first cut to June or July would therefore increase the total productivity of first growth period and extend the phase of net $\mathrm{CO}_{2}$ uptake. However, this is hardly compatible to intensive grassland management depending on profitability (McInerney, 2000) as forage quality would be too low. After a grassland cut, it took several weeks until the sites showed net $\mathrm{CO}_{2}$ uptake again, often closely followed by the next cutting (Fig. 5). Therefore, the cutting regime strongly controlled the NEE of the agricultural grassland sites.

Unutilized peatland ecosystems can either be source or sink of $\mathrm{CO}_{2}$, depending on variables like trophic status, peat temperature, water table (Bubier et al., 1998) or vegetation composition (Leppälä et al., 2011). As the difference between uptake (GPP) and release of $\mathrm{CO}_{2}\left(R_{\mathrm{ECO}}\right)$ is generally small, marginal changes of these parameters can invert the NEE of a peatland between different years (Bubier et al., 1999; Griffis et al., 2000; Arneth et al., 2002). At site UG, maximum daily GPP was observed in July, followed by a decrease in August, while $R_{\mathrm{ECO}}$ reached its maximum a few

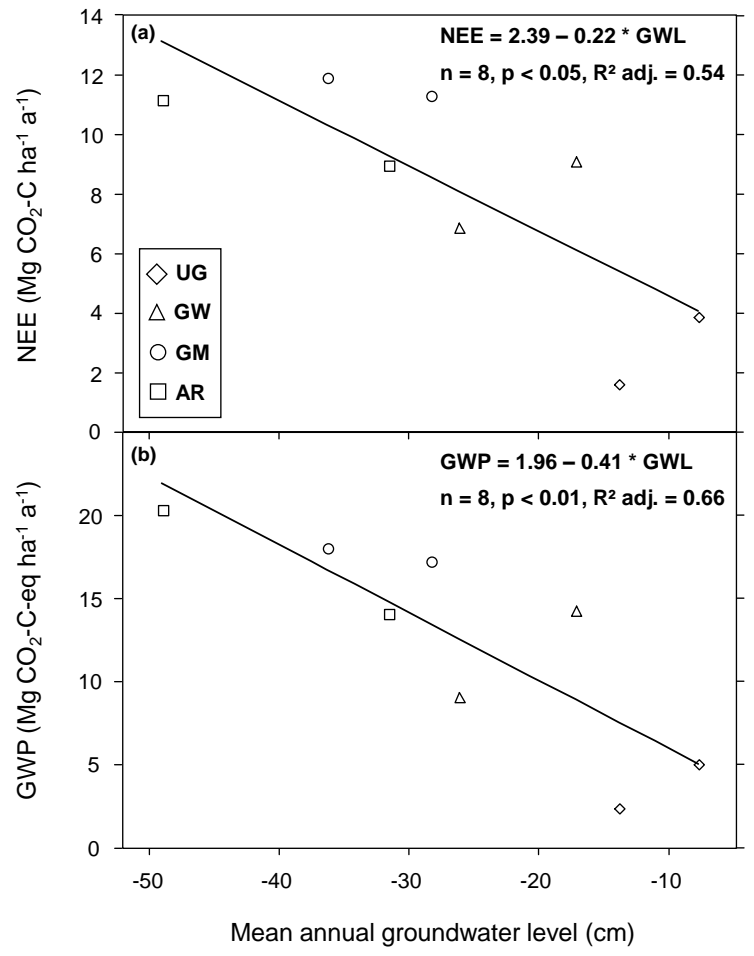

Figure 12. Effect of mean annual groundwater level on net ecosystem exchange (NEE) of $\mathrm{CO}_{2}$ (a) and global warming potential (GWP) of the four study sites (b) during the period April 2012March 2014. GWL in the equations is the mean annual groundwater level $(\mathrm{cm})$.

weeks later, then declined to a lesser extent. This was typical as the annual course of $R_{\mathrm{ECO}}$ is usually shifted by about 1 month compared to GPP (Lloyd and Taylor, 1994). Consequently, daily net $\mathrm{CO}_{2}$ uptake reaches its maximum in spring or early summer and a net release of $\mathrm{CO}_{2}$ starts in late summer when vegetation becomes senescent and $R_{\mathrm{ECO}}$ exceeds GPP (Bellisario et al., 1998; Parsons and Chapman, 2000). A late cutting of vegetation could delay senescence and prolong the period of plant growth at site UG, which might reduce NEE. However, Beetz et al. (2013) observed that a single cutting event shifted a rewetted and extensively used peat bog grassland from a $\mathrm{CO}_{2}$ sink to a small source as annual GPP was reduced by more than annual $R_{\mathrm{ECO}}$. This cutting was, however, conducted at the end of vegetation period and GPP did not rise again. The optimum time for a one-cut grassland system in terms of maximizing GPP by avoiding early senescence might be in late July or early August to take advantage of both a highly productive primary growth and regrowth period. In addition, this was usually the period of lowest groundwater levels (Fig. 2), ensuring the viability of a grassland cutting as the limit for trafficability on fen soils is a GWL around $-30 \mathrm{~cm}$ (Blankenburg et al., 2001). However, a potentially smaller NEE of a one-cut system might be offset by an increase in NECB due to biomass removal. 
At site AR, the change of management with undersown grass in 2013 greatly influenced the courses and annual sums of GPP and $R_{\mathrm{ECO}}$ (Table 2 and Fig. 5). Both increased in the second year due to a continuous plant cover but with a larger increase of $R_{\mathrm{ECO}}$, resulting in a higher NEE. As the C export by harvest also increased considerably (Table 3), the change of NECB was even greater than for NEE. In 2012, no plants remained on the site after pesticide application and mulching in September, eliminating GPP and autotrophic respiration $\left(R_{\mathrm{a}}\right)$. Due to a wet summer, harvest was conducted late and in spite of a high GWL, which induced soil compaction. In combination with the lack of water removal by plants, this led to inundation during autumn and winter. As a consequence, soil respiration was low during winter 2012/13 (Fig. 5). In contrast, $R_{\mathrm{ECO}}$ and GPP fluxes were higher in winter 2013/14 and considerably increased at the end of the study period due to highly productive new established grass, a lower GWL (Fig. 2) and higher temperatures (Fig. 1).

Several studies observed increasing $\mathrm{CO}_{2}$ emissions from peatland ecosystems with increasing drainage intensity (e.g., Moore and Knowles, 1989; Bubier et al., 1998; Drösler, 2005; Dinsmore et al., 2009). Since the variability of NEE for an individual agricultural site strongly depends on management (Wohlfahrt et al., 2008b) as described above, intersite comparison is necessary to illustrate the effect of water level on NEE. Based on an average of the four study sites and both years, NEE significantly increased by about $220 \mathrm{~kg} \mathrm{CO}_{2}-\mathrm{Cha}^{-1} \mathrm{a}^{-1}$ per $\mathrm{cm}$ lowering of mean annual GWL (Fig. 12a). Moreover, our results suggest that arable cropping of peatlands did not lead to higher $\mathrm{CO}_{2}$ emissions per se, confirming recent observations from peatland sites in Germany (Drösler et al., 2013) and Denmark (Elsgaard et al., 2012). Despite a lower mean annual GWL on site AR (Table 1), NEE and NECB of sites AR and GM did not differ significantly (Fig. 7). This can be explained by a lower $R_{\mathrm{ECO}}$ due to missing vegetation cover and water logging after harvest at site AR in the first year and a very high GPP due to undersown grass in the second year. Furthermore, EstopAragonés et al. (2012) argue that in compacted peat soils with high bulk densities and ash contents, oxygen penetration is reduced compared to less compacted soils, resulting in lower air-filled porosity and soil respiration. Due to the higher peat degradation of site AR (Table 1), this could partly explain the similar NEE of sites AR and GM.

While Aurela et al. (2007) reported that a drought period in a Finnish sedge fen increased $R_{\mathrm{ECO}}$ and thus NEE, Leppälä et al. (2011) concluded that the difference in NEE between wet and dry years for natural peatlands in Finland resulted from alterations of GPP rather than $R_{\mathrm{ECO}}$. For the dryer second year of our observations, $R_{\mathrm{ECO}}$ of site UG was lower than in the first year, while GPP decreased only marginally (Table 2). However, comparing only July and August, the period with greatest difference in GWLs between the years $(-9.2 \mathrm{~cm}$ in 2012 and $-36.6 \mathrm{~cm}$ in 2013; Fig. 2$), R_{\mathrm{ECO}}$ was almost the same $\left(6.9\right.$ and $6.8 \mathrm{Mg} \mathrm{CO}_{2}-\mathrm{Cha}^{-1}$ in 2012 and
2013, respectively), which is in line with results presented by Parmentier et al. (2009) and Muhr et al. (2011). GPP slightly increased in the drier year $\left(-7.2\right.$ and $-7.6 \mathrm{MgCO}_{2}-$ $\mathrm{C} \mathrm{ha}^{-1}$ in 2012 and 2013, respectively). As the main reason for differences in NEE between the 2 years, the weather conditions in spring could be identified. In 2012, the growing season, calculated by the method of Janssens (2010), started on 20 March, while it was delayed by more than 1 month in 2013 to 23 April. As a result of different weather conditions, cumulated $R_{\mathrm{ECO}}$ for April and May was $4.1 \mathrm{Mg}$ in 2012 and only $2.2 \mathrm{Mg} \mathrm{CO}_{2}-\mathrm{Cha}^{-1}$ in 2013. Besides, GPP was $-3.2 \mathrm{Mg}$ for April and May 2012 and $-2.3 \mathrm{MgCO}_{2}$ $\mathrm{Cha}^{-1}$ in 2013. These differences cannot be explained by mean GWL for the 2 months $(-4.9 \mathrm{~cm}$ in 2012 and $-8.4 \mathrm{~cm}$ in 2013) as the different weather conditions were the dominating parameter. Thus, respiration processes were stimulated more than plant productivity by the earlier start of growing season, indicating that shorter winter periods potentially increase the risk of higher $\mathrm{C}$ losses from peatland ecosystems. Griffis et al. (2000) studied the NEE of a subarctic fen and concluded that the phenological stage of vegetation relative to the climatic conditions is important for interannual variability of NEE. In conclusion, the mean GWL of single years cannot be solely used to predict the variability of NEE at the same site or between sites with different management as climatic and management effects can be of dominating importance.

\subsection{Global warming potential}

The global warming potential (GWP) of the four study sites increased in the same order as NEE and NECB. However, the difference between sites GW and AR was significant for GWP, whereas it was not significant for NEE and NECB (Fig. 7). This can be explained by significantly higher $\mathrm{N}_{2} \mathrm{O}$ emissions at site AR (Fig. 6b). NEE mainly controlled the GHG balances, accounting for 72, 69, 66 and $59 \%$ of the GWP on sites UG, GW, GM and AR, respectively. In addition, the balances of $\mathrm{C}$ export via harvest and $\mathrm{C}$ import via slurry contributed considerably to the GWP of the agricultural sites, accounting for 21,23 and $27 \%$ for sites GW, GM and AR, respectively, indicating a higher share of anthropogenic $\mathrm{C}$ fluxes with higher land use intensity. Compared to other observations or reviews of peatland GHG emissions in northern or temperate Europe, the GWP of the study sites was at the upper end of presented emission factors (Nykänen et al., 1995; Langeveld et al., 1997; Kasimir-Klemedtsson et al., 1997; Alm et al., 2007a; Oleszczuk et al., 2008; Maljanen et al., 2010; Drösler et al., 2013).

Site UG showed a significantly lower GWP compared to the agricultural sites, supporting the assumption that rewetting of drained organic soils reduces their climatic footprint (Höper et al., 2008; Beetz et al., 2013). The lower GWP of site UG was a result of missing $\mathrm{C}$ losses through harvest and reduced $\mathrm{CO}_{2}$ and $\mathrm{N}_{2} \mathrm{O}$ emissions that could mainly 
be attributed to the high GWLs (Fig. 12b), outweighing the higher $\mathrm{CH}_{4}$ release (Fig. 6a). A linear regression for all four sites and both years gave a significant increase of GWP for about $410 \mathrm{~kg} \mathrm{CO}_{2}-\mathrm{C}$ eq. ha $\mathrm{ha}^{-1} \mathrm{a}^{-1}$ per $\mathrm{cm}$ lowering of mean annual GWL (Fig. 12b). The higher slope compared to NEE (Fig. 12a) was a result of $\mathrm{N}_{2} \mathrm{O}$ emissions, significantly increasing with drainage intensity as well (Fig. 10b). However, as $\mathrm{CH}_{4}$ emissions tended to increase exponentially when water levels were close to the soil surface (Fig. 10a), the slope might decline or even invert for a mean annual GWL around or above 0 (Augustin and Joosten, 2007). Therefore, the intercept of $\sim 2 \mathrm{MgCO}_{2}-\mathrm{C}$ eq. ha ${ }^{-1} \mathrm{a}^{-1}$ should not be overinterpreted. A mean annual GWL of about $10 \mathrm{~cm}$ below the soil surface is often referred to as an optimum scenario for mitigating $\mathrm{GHG}$ emissions from peatlands, as $\mathrm{CO}_{2}$ emissions are greatly reduced or even negative (i.e., $\mathrm{CO}_{2}$ uptake) and $\mathrm{CH}_{4}$ fluxes are hampered by the small oxic horizon (e.g., Couwenberg et al., 2011). However, this is not only controlled by mean annual GWL but equally by groundwater fluctuations (Dinsmore et al., 2009). Thus, the relatively high GWP of site UG (3.8 $\mathrm{MgCO}_{2}-\mathrm{C}$ eq. $\left.\mathrm{ha}^{-1} \mathrm{a}^{-1}\right)$ in spite of a high mean annual GWL (Table 1) suggests that a further increase and stabilization of water levels might be necessary to reduce the climatic impact of that site. The lack of natural, peat-forming mire vegetation (Table 1) supports this assumption as the GWP of natural or rewetted reed and sedge fens is assumed to be around $1 \mathrm{MgCO}_{2}-\mathrm{C}$ eq. ha $\mathrm{ha}^{-1} \mathrm{a}^{-1}$ (Couwenberg et al., 2011; Drösler et al., 2013).

\subsection{Yield-related emissions}

To assess the climatic footprint of the agricultural study sites, their function in terms of forage and milk production has to be considered in addition to area-related GHG emissions. Based on an average of 2 years, site GW represented the most climate-efficient forage production system of the three sites, whereas site AR caused the greatest GHG emissions relative to energy yield (Table 4). Observations of greenhouse gas emissions from arable forage cropping systems at two sites on mineral soil in northern Germany resulted in yield-related emissions between -18 and $32.5 \mathrm{~kg} \mathrm{CO}_{2}-\mathrm{C}$ eq. (GJ NEL) ${ }^{-1}$, including all emissions during crop production, transport and storage (Herrmann et al., 2014). Hence, the field-based emissions at the study sites presented here, demonstrate that forage produced on fen soils is burdened with many times higher GHG emissions compared to forage from mineral soils of the same region.

The high yield-related emissions of site AR were mainly attributed to the low energy yield of barley in the first year, resulting from wet conditions in summer and thus a delayed harvest with low quality for milk production. In addition, the site was only partially harvested due to high soil moisture, thus, the true yield per hectare was even lower than given in Table 3. Moreover, the silage maize in 2011 could not be harvested at all due to above-average precipitation in $\mathrm{Au}-$ gust and September (Fig. 1). Therefore, arable forage production on fen soils of the study area is associated with a high uncertainty of yield in wet years, which, considering the high GHG emissions, makes it an inappropriate type of management from both an economic and environmental point of view. Underlining this conclusion, the management of site AR was changed in 2013 with undersown grass, increasing the certainty of yield as the time of harvest became more flexible. However, despite a high yield in 2013, yield-related emissions remained higher compared to site $\mathrm{GW}$ as a result of a very high GWP (Table 2).

Comparing the two grassland sites, the four-cut system of site GM in 2013 showed the highest and the three-cut system of site GW in 2013 induced lowest yield-related GHG emissions. In addition, the two-cut system of site GW in 2012 had higher yield-related emissions than the three-cut systems of both sites. Therefore, a three-cut grassland in combination with a preferably high GWL represented the most climateefficient management system at the studied fen soils. Based on an average of both years, the energy yield of site GW was $19 \%$ lower compared to site GM, while the GWP was $34 \%$ lower. This difference was only significant for GWP. Thus, the effect of a raised water level can be assumed to be greater for GHG emission reduction than for yield reduction. This is in line with results of Renger et al. (2002), who reported that for a mean GWL of $-30 \mathrm{~cm}, 90 \%$ of optimum plant output can be reached, while GHG emissions can be reduced for 40 $50 \%$ of maximum emissions. These values were obtained by a water regime model and represent an optimum scenario, indicating that further potential exists to improve the climate efficiency of forage production on site GW. Reasons for reduced productivity on poorly drained soils could include the loss of sown species in favor of undesirable species with increasing sward age (Hopkins and Green, 1979) and a lower soil warming in spring due to high soil moisture, resulting in delayed plant growth (Tyson et al., 1992). The first aspect was evident in increasing shares of creeping bentgrass (Agrostis stolonifera) and water foxtail (Alopecurus geniculatus) at site $\mathrm{GW}$, indicating the need for occasional resowing of productive species like perennial ryegrass (Lolium perenne).

None of the conventional management options can be regarded as sustainable in terms of peat conservation as each type of utilization associated with peatland drainage led to peat mineralization (Joosten and Clarke, 2002; Renger et al., 2002). The ongoing subsidence due to peat loss might change the utilization structure in future as sites become wetter and some areas might need to be extensified or abandoned, opening potentials for GHG mitigation. This was recently evident at site $\mathrm{GW}$, where only two cuts could be realized in the wet years 2011 and 2012. 


\section{Conclusions}

Long-term drainage intensity was the most important controlling factor for GHG emissions from the studied fen soils. NEE dominated the GHG balances of all sites and as assumed, considerable differences in GHG fluxes and balances were observed among the sites. After 20 years of rewetting (site UG), emissions of $\mathrm{CO}_{2}$ and $\mathrm{N}_{2} \mathrm{O}$ were significantly lower while significantly higher amounts of $\mathrm{CH}_{4}$ were emitted compared to the agricultural sites. Also, the GWP of site UG was significantly reduced. However, the site still acted as a $\mathrm{C}$ source and showed substantial $\mathrm{N}_{2} \mathrm{O}$ emissions, indicating that rewetting had not yet restored the natural peatland functioning as a sink for $\mathrm{C}$ and a negligible source for $\mathrm{N}_{2} \mathrm{O}$. Restoration progress could be promoted by a year-round stabilization of GWL close to the soil surface. In the current state, a mulching of vegetation in summer might increase total annual productivity by avoiding early senescence and thus reduce $\mathrm{C}$ losses.

Arable forage production (site AR) did not induce higher $\mathrm{C}$ losses compared to intensive grassland management and only showed a significantly higher GWP than the wet grassland site (GW) as the influence of drainage intensity was of dominating importance. However, interannual on-site variability was additionally affected by management and climatic factors. The beginning of growing season was identified as a critical period, with higher $\mathrm{CO}_{2}$ losses occurring with an early start of vegetation period. Yield-related GHG emissions increased with increasing drainage and land use intensity in the order GW, GM and AR, with a significant difference between sites GW and AR.

As arable cropping was associated with a high uncertainty of yield and a high GWP, this type of management was identified as unsuitable for forage production on fen soils. The wet grassland site (GW) realized lowest yield-related emissions due to a significantly lower GWP in combination with a non-significantly reduced energy yield compared to sites GM and AR. Thus, this study demonstrated that there is huge potential for GHG mitigation in intensively utilized peatland areas of northern Germany which could be realized without eliminating traditional forage production. Reducing the land use intensity (low $\mathrm{N}$ fertilization, late first cut) of increasingly inundating areas as a consequence of peat loss, could further enhance GHG mitigation and additionally promote nature conservation purposes (particularly meadow bird protection)

\section{The Supplement related to this article is available online at doi:10.5194/bg-13-5221-2016-supplement.}

Acknowledgements. This study was funded by the former Innovationsstiftung Schleswig-Holstein (ISH) foundation and the Ministry of Energy, Agriculture, the Environment and Rural Areas of the Federal State of Schleswig-Holstein (MELUR). Their financial support is grateful acknowledged. The selection of study sites was supported by the State Office of Agriculture, the Environment and Rural Areas (LLUR). We thank the three farmers of the study sites for their cooperation and the foundation for nature conservation (Stiftung Naturschutz) of Schleswig-Holstein for the permission to conduct our measurements in a nature conservation area. Further thanks go to Howard Skinner for reviewing the manuscript in terms of linguistic issues and Mario Hasler for his advice on the statistical analyses.

Edited by: I. Trebs

Reviewed by: D. Sihi and three anonymous referees

\section{References}

Akaike, H.: A new look at the statistical model identification, IEEE T. Automat. Contr., 19, 716-723, doi:10.1109/TAC.1974.1100705, 1974.

Alm, J., Shurpali, N. J., Minkkinen, K., Aro, L., Hytönen, J., Laurila, T., Lohila, A., Maljanen, M., Martikainen, P. J., Mäkiranta, P., Penttilä, P., Saarnio, S., Silvan, N., Tuittila, E.-S., and Laine, J.: Emission factors and their uncertainty for the exchange of $\mathrm{CO}_{2}, \mathrm{CH}_{4}$ and $\mathrm{N}_{2} \mathrm{O}$ in Finnish managed peatlands, Boreal Environ. Res., 12, 191-209, 2007a.

Alm, J., Shurpali, N. J., Tuittila, E.-V., Laurila, T., Maljanen, M., Saarnio, S., and Minkkinen, K.: Methods for determining emission factors for the use of peat and peatlands - flux measurements and modelling, Boreal Environ. Res., 12, 85-100, 2007b.

Arneth, A., Kurbatova, J., Kolle, O., Shibistova, O. B., Lloyd, J., Vygodskaya, N. N., and Schulze, E.-D.: Comparative ecosystem-atmosphere exchange of energy and mass in a European Russian and a central Siberian bog II, Interseasonal and interannual variability of $\mathrm{CO}_{2}$ fluxes, Tellus, 54B, 514-530, doi:10.1034/j.1600-0889.2002.01349.x, 2002.

Augustin, J. and Joosten, H.: Peatland rewetting and the greenhouse effect, Int. Mire Conserv Group Newsl., 3, 29-30, 2007.

Aurela, M., Riutta, T., Laurila, T., Tuovinen, J.-P., Vesala, T., Tuittila, E.-S., Rinne, J., Haapanala, S., and Laine, J.: $\mathrm{CO}_{2}$ exchange of a sedge fen in southern Finland - the impact of a drought period, Tellus, 59B, 826-837, doi:10.1111/j.16000889.2007.00309.x, 2007.

Baker, C. W. and Barnes, R.: The application of near infra-red spectrometry to forage evaluation in the agricultural developement and advisory service, in: Feedstuff evaluation, edited by: Wiseman, J. and Cole, D. J. A., Butterworths, London, 337-351, 1990.

Beetz, S., Liebersbach, H., Glatzel, S., Jurasinski, G., Buczko, U., and Höper, H.: Effects of land use intensity on the full greenhouse gas balance in an Atlantic peat bog, Biogeosciences, 10, 1067-1082, doi:10.5194/bg-10-1067-2013, 2013.

Bellisario, L. M., Moore, T. R., and Bubier, J. L.: Net ecosystem $\mathrm{CO}_{2}$ exchange in a boreal peatland, northern Manitoba, Écoscience, 5, 534-541, 1998.

Beyer, C. and Höper, H.: Greenhouse gas exchange of rewetted bog peat extraction sites and a Sphagnum cultivation site in north- 
west Germany, Biogeosciences, 12, 2101-2117, doi:10.5194/bg12-2101-2015, 2015.

Blankenburg, J., Hennings, H. H., and Schmidt, W.: Bodenphysikalische Eigenschaften und Wiedervernässung, in: Ökosystemmanagement für Niedermoore - Strategien und Verfahren zur Renaturierung, edited by: Kratz, R. and Pfadenhauer, J., Eugen Ulmer, Stuttgart, 81-91, 2001.

Blume, H.-P. and Brümmer, G.: Agriculture, landscapes and soils of Schleswig-Holstein, Mitt. Dtsch. Bodenkdl. Ges., 51, 3-14, 1986.

Bouwman, A. F., Boumans, L. M., and Batjes, N. H.: Emissions of $\mathrm{N}_{2} \mathrm{O}$ and $\mathrm{NO}$ from fertilized fields: summary of available measurement data, Global Biogeochem. Cy., 16, 1-6, doi:10.1029/2001GB001811, 2002.

Bretz, F., Hothorn, T., and Westfall, P.: Multiple comparisons using R, Chapman \& Hall, CRC Press, London, 2011.

Bubier, J. L. and Moore, T. R.: An ecological perspective on methane emissions from northern wetlands, Trends Ecol. Evol., 9, 460-464, doi:10.1016/0169-5347(94)90309-3, 1994.

Bubier, J. L., Crill, P. M., Moore, T. R., Savage, K., and Varner, R. K.: Seasonal patterns and controls on net ecosystem $\mathrm{CO}_{2}$ exchange in a boreal peatland complex, Global Biochem. Cy., 12, 703-714, doi:10.1029/98GB02426, 1998.

Bubier, J. L., Frolking, S., Crill, P. M., and Linder, E.: Net ecosystem productivity and its uncertainty in a diverse boreal peatland, J. Geophys. Res., 104, 27683-27692, doi:10.1029/1999JD900219, 1999.

Byrne, K. A., Chojnicki, B., Christensen, T. R., Drösler, M., Freibauer, A., Friborg, T., Frolking, S., Lindroth, A., Mailhammer, J., Malmer, N., Selin, P.; Turunen, J., Valentini, R., and Zetterberg, L.: EU peatlands: Current carbon stocks and trace gas fluxes, Carbo-Europe-GHG Concerted Action-Synthesis of the European Greenhouse Gas Budget, Report 4, Lund, 2004.

Chapin, F. S., Woodwell, G. M., Randerson, J. T., Rastetter, E. B., Lovett, G. M., Baldocchi, D. D., Clark, D. A., Harmon, M. E., Schimel, D. S., Valentini, R., Wirth, C., Aber, J. D., Cole, J. J., Goulden, M. L., Harden, J. W., Heimann, M., Howarth, R. W., Matson, P. A., McGuire, A. D., Melillo, J. M., Mooney, H. A., Neff, J. C., Houghton, R. A., Pace, M. L., Ryan, M. G., Running, S. W., Sala, O. E., Schlesinger, W. H., and Schulze, E.-D.: Reconciling carbon cycle concepts, terminology, and methods, Ecosystems, 9, 1041-1050, doi:10.1007/s10021-005-0105-7, 2006.

Chapuis-Lardy, L., Wrage, N., Metay, A., Chotte, J.-L., and Bernoux, M.: Soils, a sink for $\mathrm{N}_{2} \mathrm{O}$ ? A review, Glob. Change Biol., 13, 1-17, doi:10.1111/j.1365-2486.2006.01280.x, 2007.

Chatskikh, D., Olesen, J. E., Hansen, E. M., Elsgaard, L., and Petersen, B. M.: Effects of reduced tillage on net greenhouse gas fluxes from loamy sand soil under winter crops in Denmark, Agr. Ecosys. Environ., 128, 117-126, doi:10.1016/j.agee.2008.05.010, 2008

Couwenberg, J.: Methane emissions from peat soils (organic soils, histosols) - Facts, mrv-ability, emission factors, Wetlands International, Ede, 2009a.

Couwenberg, J.: Emission factors for managed peat soils (organic soils, histosols) - An analysis of IPCC default values, Wetlands International, Ede, 2009b.

Couwenberg, J.: Greenhouse gas emissions from managed peat soils: Is the IPCC reporting guidance realistic?, Mires Peat, 8, $1-10,2011$.
Couwenberg, J., Thiele, A., Tanneberger, F., Augustin, J., Bärisch, S., Dubovik, D., Liashchynskaya, N., Michaelis, D., Minke, M., Skuratovich, A., and Joosten, H.: Assessing greenhouse gas emissions from peatlands using vegatation as a proxy, Hydrobiologia, 674, 67-89, doi:10.1007/s10750-011-0729-x, 2011.

Davidson, E. A., Savage, K., Verchot, L. V., and Navarro, R.: Minimizing artifacts and biases in chamber-based measurements of soil respiration, Agr. Forest Meteorol., 113, 21-37, doi:10.1016/S0168-1923(02)00100-4, 2002.

Dinsmore, K. J., Skiba, U. M., Billett, M. F., and Rees, R. M.: Effect of water table on greenhouse gas emissions from peatland mesocosms, Plant Soil, 318, 229-242, doi:10.1007/s11104-0089832-9, 2009.

Dixon, R. K., Brown, S., Houghton, R. A., Solomon, A. M., Trexler, M. C., and Wisniewski, J.: Carbon pools and flux of global forest ecosystems, Science, 263, 185-190, doi:10.1126/science.263.5144.185, 1994.

Dowrick, D. J., Hughes, S., Freeman, C., Lock, M. A., Reynolds, B., and Hudson, J. A.: Nitrous oxide emissions from gully mire in mid-Wales, UK, under simulated summer drought, Biogeochemistry, 44, 151-162, doi:10.1023/A:1006031731037, 1999.

Drösler, M.: Trace gas exchange and climatic relevance of bog ecosystems, Southern Germany, PhD thesis, Technische Universität München, Germany, 2005.

Drösler, M., Freibauer, A., Christensen, T. R., and Friborg, T.: Observations and status of peatland greenhouse gas emissions in Europe, in: Dolman, A. J., Valentini, R., and Freibauer, A. (Eds.): The continental-scale greenhouse gas balance of Europe, Springer, New York, 243-261, 2008.

Drösler, M., Adelmann, W., Augustin, J., Gergmann, L., Beyer, C., Chojnicki, B., Förster, C., Freibauer, A., Giebels, M., Görlitz, S., Höper, H., Kantelhardt, J., Liebersbach, H., Hahn-Schöfl, M., Minke, M., Petschow, U., Pfadenhauer, J., Schaller, L., Schägner, P., Sommer, M., Thuille, A., and Wehrhan, M.: Klimaschutz durch Moorschutz, Schlussbericht des Vorhabens "Klimaschutz - Moorschutzstrategien”, 2006-2013, 2013.

Dunfield, P., Knowles, R., Dumont, R., and Moore, T. R.: Methane production and consumption in temperate and subarctic peat soils: Response to temperature and $\mathrm{pH}$, Soil Biol. Biochem., 25, 321-326, doi:10.1016/0038-0717(93)90130-4, 1993.

Elsgaard, L., Görres, C.-M., Hoffmann, C. C., Blicher-Mathiesen, G., Schelde, K., and Petersen, S. O.: Net ecosystem exchange of $\mathrm{CO}_{2}$ and carbon balance for eight temperate organic soils under agricultural management, Agr. Ecosys. Environ., 162, 52-67, doi:10.1016/j.agee.2012.09.001, 2012.

Estop-Aragonés, C. and Blodau, C.: Effects of experimental drying intensity and duration on respiration and methane production recovery in fen peat incubations, Soil Biol. Biochem., 47, 1-9, doi:10.1016/j.soilbio.2011.12.008, 2012.

Estop-Aragonés, C., Knorr, K.-H., and Blodau, C.: Controls on in situ oxygen and dissolved inorganic carbon dynamics in peats of a temperate fen, J. Geophys. Res., 117, G02002, doi:10.1029/2011JG001888, 2012.

FAO: World reference base for soil resources 2006 - a framework for international classification, correlation and communication, FAO, Rome, 2006.

Farquharson, R. and Baldock, J.: Concepts in modelling $\mathrm{N}_{2} \mathrm{O}$ emissions from land use, Plant Soil, 309, 147-167, doi:10.1007/s11104-007-9485-0, 2008. 
Firestone, M. K., Firestone, R. B., and Tiedje, J. M.: Nitrous oxide from soil denitrification: Factors controlling its biological production, Science, 208, 749-751, doi:10.1126/science.208.4445.749, 1980.

Flessa, H., Wild, U., Klemisch, M., and Pfadenhauer, J.: Nitrous oxide and methane fluxes from organic soils under agriculture, Eur. J. Soil. Sci., 49, 327-335, doi:10.1046/j.13652389.1998.00156.x, 1998.

GfE: New equations for predicting metabolizable energy of grass and maize products for ruminants, P. Soc. Nutr. Physiol., 17, 191-197, 2008

Glatzel, S. and Well, R.: Evaluation of septum-capped vials for storage of gas samples during air transport, Environ. Monit. Assess., 136, 307-311, doi:10.1007/s10661-007-9686-2, 2008.

Goldberg, S. D., Knorr, K.-H., Blodau, C., Lischeid, G., and Gebauer, G.: Impact of altering the water table height of an acidic fen on $\mathrm{N}_{2} \mathrm{O}$ and $\mathrm{NO}$ fluxes and soil concentrations, Glob. Change Biol., 16, 220-233, doi:10.1111/j.13652486.2009.02015.x, 2010.

Gorham, E. and Rochefort, L.: Petaland restoration: A brief assessment with special reference to Sphagnum bogs, Wetl. Ecol. Manag., 11, 109-119, doi:10.1023/A:1022065723511, 2003.

Görres, C.-M., Conrad, R., and Petersen, S. O.: Effect of soil properties and hydrology on Archeal community composition in three temperate grasslands on peat, FEMS Microbiol. Ecol., 85, 227240, doi:10.1111/1574-6941.12115, 2013.

Grant, R. F., Pattey, E., Goddard, T. W., Kryzanowski, L. M., and Puurveen, H.: Modeling the effects of fertilizer application rate on nitrous oxide emissions, Soil Sci. Soc. Am. J., 70, 235-248, doi:10.2136/sssaj2005.0104, 2006.

Griffis, T. J., Rouse, W. R., and Waddington, J. M.: Interannual variability of net ecosystem $\mathrm{CO}_{2}$ exchange at a subarctic fen, Global Biogeochem. Cy., 14, 1109-1121, doi:10.1029/1999GB001243, 2000.

Grosse-Brauckmann, G.: Moore und Moor-Naturschutzgebiete in Deutschland - eine Bestandsaufnahme, Telma, 27, 183-215, 1997.

Hahn-Schöfl, M., Zak, D., Minke, M., Gelbrecht, J., Augustin, J., and Freibauer, A.: Organic sediment formed during inundation of a degraded fen grassland emits large fluxes of $\mathrm{CH}_{4}$ and $\mathrm{CO}_{2}$, Biogeosciences, 8, 1539-1550, doi:10.5194/bg-8-15392011, 2011.

HBU: Handbook of soil analyses (HBU), Soil quality - Determination of dry bulk density Berlin, Beuth Verlag GmbH, ISO 11272, 10 pp., 1998

Herrmann, A., Claus, S., Loges, R., Kluß, C., and Taube, F.: Can arable forage production be intensified sustainably? A case study from northern Germany, Crop. Pasture Sci., 65, 538-549, doi:10.1071/CP13362, 2014.

Hopkins, A. and Green, J. O.: The effect of soil fertility and drainage on sward changes, in: Changes in sward composition and productivity, edited by: Charles, A. H. and Haggar, R. J., British Grassland Society, Hurley, 115-129, 1979.

Höper, H.: Carbon and nitrogen mineralisation rates of fens in Germany used for agriculture, A review, in: Wetlands in Central Europe - soil organisms, soil ecological processes and trace gas emissions, edited by: Broll, G., Merbach, W., and Pfeiffer, E.M., Springer, Berlin, 149-164, 2002.
Höper, H., Augustin, J., Cagampan, J. P., Drösler, M., Lundin, L., Moors, E., Vasander, H, Waddington, J. M., and Wilson, D.: Restoration of peatlands and greenhouse gas balances, in: Peatlands and climate change, edited by: Strack, M., International Peat Society, Jyväskylä, 182-210, 2008.

Hutchinson, G. L. and Mosier, A. R.: Improved soil cover method for field measurement of nitrous oxide fluxes, Soil Sci. Soc. Am. J., 45, 311-316, doi:10.2136/sssaj1981.03615995004500020017x, 1981.

IPCC: Climate change 2007: The physical science basis, Contribution of working group I to the fourth assessment report of the International Panel on Climate Change, edited by: Solomon, S., Qin, D., Manning, M., Chen, Z., Marquis, M., Averyt, K. B., Tignor, M., and Miller, H. L., Cambridge University Press, Cambridge, New York, 2007.

IPCC: 2013 Supplement to the 2006 IPCC Guidelines for National Greenhouse Gas Inventories: Wetlands, edited by: Hirashi, T., Krug, T., Tanabe, K., Srivastava, N., Baasansuren, J., Fukuda, M., and Troxler, T. G., IPCC, Switzerland, 2014.

Janssens, W.: Defining the vegetation period by temperature sums, Proc 7th Conf Biometeorology, Freiburg, 312-318, 2010.

Joosten, H.: The Global Peatland $\mathrm{CO}_{2}$ Picture - Peatland status and emissions in all countries of the world, Wetlands International, Ede, 2009.

Joosten, H. and Clarke, D.: Wise use of mires and peatlands - Background and principles including a framework for decision making, International Mire Conservation Group and International Peat Society, Saarijärvi, 2002.

Jørgensen, C. J. and Elberling, B.: Effects of flooding-induced $\mathrm{N}_{2} \mathrm{O}$ production, consumption and emission dynamics on the annual $\mathrm{N}_{2} \mathrm{O}$ emission budget in wetland soil, Soil Biol. Biochem., 53, 9-17, doi:10.1016/j.soilbio.2012.05.005, 2012.

Kasimir-Klemdtsson, A., Klemdtsson, L., Berglund, K., Martikainen, P., Silvola, J., and Oenema, O.: Greenhouse gas emissions from farmed organic soils: A review, Soil Use Manage., 13, 245-250, doi:10.1111/j.1475-2743.1997.tb00595.x, 1997.

Knorr, K.-H., Glaser, B., and Blodau, C.: Fluxes and ${ }^{13} \mathrm{C}$ isotopic composition of dissolved carbon and pathways of methanogenesis in a fen soil exposed to experimental drought, Biogeosciences, 5, 1457-1473, doi:10.5194/bg-5-1457-2008, 2008.

Koops, J. G., van Beusichem, M. L., and Oenema, O.: Nitrogen loss from grassland on peat soils through nitrous oxide production, Plant Soil, 188, 119-130, doi:10.1023/A:1004252012290, 1997.

Koponen, H. T., Escude Duran, C., Maljanen, M., Hytönen, J., and Martikainen, P. J.: Temperature responses of $\mathrm{NO}$ and $\mathrm{N}_{2} \mathrm{O}$ emissions from boreal organic soil, Soil Biol. Biochem., 38, 17791787, doi:10.1016/j.soilbio.2005.12.004, 2006.

Laird, N. M. and Ware, J. H.: Random-effects models for longitudinal data, Biometrics, 38, 963-974, doi:10.2307/2529876, 1982.

Langeveld, C. A., Segers, R., Dirks, B. O., van den Pol-van Dasselaar, A., Velthof, G. L., and Hensen, A.: Emissions of $\mathrm{CO}_{2}, \mathrm{CH}_{4}$ and $\mathrm{N}_{2} \mathrm{O}$ from pasture on drained peat soils in the Netherlands, Eur. J. Agron., 7, 35-42, doi:10.1016/S1161-0301(97)00036-1, 1997.

Leiber-Sauheitl, K., Fuß, R., Voigt, C., and Freibauer, A.: High $\mathrm{CO}_{2}$ fluxes from grassland on histic Gleysol along soil carbon and drainage gradients, Biogeosciences, 11, 749-761, doi:10.5194/bg-11-749-2014, 2014. 
Leppälä, M., Laine, A. M., Seväkivi, M.-L., and Tuittila, E.-S.: Differences in $\mathrm{CO}_{2}$ dynamics between successional mire plant communities during wet and dry summers, J. Veg. Sci., 22, 357-366, doi:10.1111/j.1654-1103.2011.01259.x, 2011.

Leppelt, T., Dechow, R., Gebbert, S., Freibauer, A., Lohila, A., Augustin, J., Drösler, M., Fiedler, S., Glatzel, S., Höper, H., Järveoja, J., Lærke, P. E., Maljanen, M., Mander, Ü., Mäkiranta, P., Minkkinen, K., Ojanen, P., Regina, K., and Strömgren, M.: Nitrous oxide emission budgets and land-use-driven hotspots for organic soils in Europe, Biogeosciences, 11, 65956612, doi:10.5194/bg-11-6595-2014, 2014.

Levy, P. E., Gray, A., Leeson, S. R., Gaiawyn, J., Kelly, M. P. C., Cooper, M. D. A., Dinsmore, K. J., Jones, S. K., and Sheppard, L. J.: Quantification of uncertainty in trace gas fluxes measured by the static chamber method, Eur. J. Soil Sci., 62, 811-821, doi:10.1111/j.1365-2389.2011.01403.x, 2011.

Lloyd, J. and Taylor, J. A.: On the temperature dependence of soil respiration, Funct. Ecol., 8, 315-323, 1994.

Maljanen, M., Liikanen, A., Silvola, J., and Martikainen, P. J.: Methane fluxes on agricultural and forested boreal organic soils, Soil Use Manage., 19, 73-79, doi:10.1111/j.14752743.2003.tb00282.x, 2003a.

Maljanen, M., Liikanen, A., Silvola, J., and Martikainen, P. J.: Nitrous oxide emissions from boreal organic soil under different land-use, Soil Biol. Biochem., 35, 1-12, doi:10.1016/S00380717(03)00085-3, 2003b.

Maljanen, M., Komulainen, V.-M., Hytönen, J., Martikainen, P. J., and Laine, J.: Carbon dioxide, nitrous oxide and methane dynamics in boreal organic agricultural soils with different soil characteristics, Soil Biol. Biochem., 36, 1801-1808, doi:10.1016/j.soilbio.2004.05.003, 2004.

Maljanen, M., Sigurdsson, B. D., Guðmundsson, J., Óskarsson, H., Huttunen, J. T., and Martikainen, P. J.: Greenhouse gas balances of managed peatlands in the Nordic countries - present knowledge and gaps, Biogeosciences, 7, 2711-2738, doi:10.5194/bg7-2711-2010, 2010.

Martikainen, P. J., Nykänen, H., Crill, P., and Silvola, J.: Effect of a lowered water table on nitrous oxide fluxes from northern peatlands, Nature, 366, 51-53, doi:10.1038/366051a0, 1993.

McInerney, J. P.: Economic aspects of grassland production and utilization, in: Grass: Its production and utilization, edited by: Hopkins, A., Blackwell Science Ltd., Oxford, 394-428, 2000.

Michaelis, L. and Menten, M. L.: Die Kinetik der Invertinwirkung, Biochem. Z., 49, 333-369, 1913.

Moore, T. R. and Knowles, R.: The influence of water table levels on methane and carbon dioxide emissions from peatland soils, Can. J. Soil. Sci., 69, 33-38, doi:10.4141/cjss89-004, 1989.

Muhr, J., Höhle, J., Otieno, D. O., and Borken, W.: Manipulative lowering of the water table during summer does not affect $\mathrm{CO}_{2}$ emissions and uptake in a fen in Germany, Ecol. Appl., 21, 391401, doi:10.1890/09-1251.1, 2011.

Nakagawa, S., and Schielzeth, H.: A general and simple method for obtaining $R^{2}$ from generalized linear mixed-effects models, Methods Ecol. Evol., 4, 133-142, doi:10.1111/j.2041210x.2012.00261.x, 2013.

Nykänen, H., Alm, J., Lang, K., Silvola, J., and Martikainen, P. J.: Emissions of $\mathrm{CH}_{4}, \mathrm{~N}_{2} \mathrm{O}$ and $\mathrm{CO}_{2}$ from a virgin fen and a fen drained for grassland in Finland, J. Biogeogr., 22, 351-357, 1995.
Nykänen, H., Alm, J., Silvola, J., Tolonen, K., and Martikainen, P. J.: Methane fluxes on boreal peatlands of different fertility and the effect of long-term experimental lowering of the water table on flux rates, Global Biogeochem. Cy., 12, 53-69, doi:10.1029/97GB02732, 1998.

Oenema, O., de Klein, C., and Alfaro, M.: Intensification of grassland and forage use: Driving forces and constraints, Crop Pasture Sci., 65, 524-537, doi:10.1071/CP14001, 2014.

Oleszczuk, R., Regina, K., Szajdak, L., Höper, H., and Maryganova, V.: Impacts of agricultural utilization of peat soils on the greenhouse gas balance, in: Strack, M. (ed.): Peatlands and climate change, International Peat Society, Jyväskylä, 70-97, 2008.

Parmentier, F. J., van der Molen, M. K., de Jeu, R. A., Hendriks, D. M., and Dolman, A. J.: $\mathrm{CO}_{2}$ fluxes and evaporation on a peatland in the Netherlands appear not affected by water table fluctuations, Agr. Forest Meteorol., 149, 1201-1208, doi:10.1016/j.agrformet.2008.11.007, 2009.

Parsons, A. J. and Chapman, D. F.: The principles of pasture growth and utilization, in: Grass: Its production and utilization, edited by: Hopkins, A., Blackwell Science Ltd., Oxford, 31-89, 2000.

Petersen, S. O., Hoffmann, C. C., Schäfer, C.-M., BlicherMathiesen, G., Elsgaard, L., Kristensen, K., Larsen, S. E., Torp, S. B., and Greve, M. H.: Annual emissions of $\mathrm{CH}_{4}$ and $\mathrm{N}_{2} \mathrm{O}$, and ecosystem respiration, from eight organic soils in Western Denmark managed by agriculture, Biogeosciences, 9, 403-422, doi:10.5194/bg-9-403-2012, 2012.

Priemé, A. and Christensen, S.: Natural perturbations, drying wetting and freezing - thawing cycles, and the emission of nitrous oxide, carbon dioxide and methane from farmed organic soils, Soil Biol. Biochem., 33, 2083-2091, doi:10.1016/S00380717(01)00140-7, 2001.

Rasch, D., Kubinger, K. D., and Moder, K.: The two-sample $t$ test: pre-testing its assumptions does not pay off, Stat. Papers, 52, 219-231, doi:10.1007/s00362-009-0224-x, 2011.

R Core Team: R: A language and environment for statistical computing, R Foundation for Statistical Computing, available at: http://www.R-project.org/, Wien, 2014.

Regina, K., Syväsalo, E., Hannukkala, A., and Esala, M.: Fluxes of $\mathrm{N}_{2} \mathrm{O}$ from farmed peat soils in Finland, Eur. J. Soil Sci., 55, 591-599, doi:10.1111/j.1365-2389.2004.00622.x, 2004.

Regina, K., Sheehy, J., and Myllys, M.: Mitigating greenhouse gas fluxes from cultivated organic soils with raised water table, Mitig. Adapt. Strateg. Glob. Change., 20, 1529-1544, doi:10.1007/s11027-014-9559-2, 2015.

Renger, M., Wessolek, G., Schwärzel, K., Sauerbrey, R., and Siewert, C.: Aspects of peat conservation and water management, J. Plant. Nutr. Soil Sc., 165, 487-493, 2002.

Robertson, G. P., Paul, E. A., and Harwood, R. R.: Greenhouse gases in intensive agriculture: Contributions of individual gases to the radiative forcing of the atmosphere, Science, 289, 19221925, doi:10.1126/science.289.5486.1922, 2000.

Rohman, K., Jeromin, K., Kieckbusch, J., Koop, B., and StruweJuhl, B.: Europäischer Vogelschutz in Schleswig-Holstein Arten und Schutzgebiete, Landesamt für Natur und Umwelt Schleswig-Holstein, Flintbek, 2008.

Roobroeck, D., Brüggemann, N., Butterbach-Bahl, K., and Boeckx, P.: Dynamics of nitrate limitation on gaseous nitrogen exchanges from pristine peatlands, Geophys. Res. Abstr., 11, EGU200912298-3, 2009. 
Roulet, N. T., Ash, R., and Quinton, W.: Methane flux from drained northern peatlands: Effect of a persistant water table lowering on flux, Global Biogeochem. Cy., 7, 749-769, doi:10.1029/93GB01931, 1993.

Röder, N., Osterburg, B., and Nitsch, N.: Regional differences in the intensity of the utilisation of organic soils in Germany, in: Grassland farming and land management systems in mountainous regions, edited by: Pötsch, E. M., Krautzer, B., and Hopkins, A., Grassl. Sci. Eur., 16, 347-349, 2011.

Röder, N. and Osterburg, B.: The impact of map and data resolution on the determination of the agricultural utilisation of organic soils in Germany, Environ. Manage., 49, 1150-1162, doi:10.1007/s00267-012-9849-y, 2012.

Schäfer, C.-M., Elsgaard, L., Hoffmann, C. C., and Petersen, S. O.: Seasonal methane dynamics in three temperate grasslands on peat, Plant Soil, 357, 339-353, doi:10.1007/s11104-012-1168-9, 2012.

Schmitt, M., Bahn, M., Wohlfahrt, G., Tappeiner, U., and Cernusca, A.: Land use affects the net ecosystem $\mathrm{CO}_{2}$ exchange and its components in mountain grasslands, Biogeosciences, 7, 22972309, doi:10.5194/bg-7-2297-2010, 2010.

Schrautzer, J., Sival, F., Breuer, M., Runhaar, H., and Fichtner, A.: Characterizing and evaluating successional pathways of fen degradation and restoration, Ecol. Indic., 25, 108-120, doi:10.1016/j.ecolind.2012.08.018, 2013.

Senbayram, M., Chen, R., Budai, A., Bakken, L., and Dittert, K.: $\mathrm{N}_{2} \mathrm{O}$ emission and the $\mathrm{N}_{2} \mathrm{O} /\left(\mathrm{N}_{2} \mathrm{O}+\mathrm{N}_{2}\right)$ product ratio of denitrification as controlled by available carbon substrates and nitrate concentrations, Agr. Ecosys. Environ., 147, 4-12, doi:10.1016/j.agee.2011.06.022, 2012.

Silvan, N., Tuittila, E.-S., Kitunen, V., Vasander, H., and Laine, J.: Nitrate uptake by Eriophorum vaginatum controls $\mathrm{N}_{2} \mathrm{O}$ production in a restored peatland, Soil Biol. Biochem., 37, 1519-1526, doi:10.1016/j.soilbio.2005.01.006, 2005.

Smith, P., Martino, D., Cai, Z., Gwary, D., Janzen, H., Kumar, P., McCarl, B., Ogle, S., O’Mara, F., Rice, C., Scholes, B., Sirotenko, O., Howden, M., McAllister, T., Pan, G., Romanenkov, V., Schneider, U., Towprayoon, S., Wattenbach, M., and Smith, J.: Greenhouse gas mitigation in agriculture, Philos. T. R. Soc. B., 363, 789-813, doi:10.1098/rstb.2007.2184, 2008.

Soussana, J.-F., Allard, V., Pilegaard, K., Ambus, P., Amman, C., Campbell, C., Ceschia, E., Clifton-Brown, J., Czobel, S., Domingues, R., Flechard, C., Fuhrer, J., Hensen, A., Horvath, L., Jones, M., Kasper, G., Martin, C., Nagy, Z., Neftel, A., Raschi, A., Baronti, S., Rees, R. M., Skiba, U., Stefani, P., Manca, G., Sutton, M., Tuba, Z., and Valentini, R.: Full accounting of the greenhouse gas $\left(\mathrm{CO}_{2}, \mathrm{~N}_{2} \mathrm{O}, \mathrm{CH}_{4}\right)$ budget of nine European grassland sites, Agr. Ecosys. Environ., 121, 121-134, doi:10.1016/j.agee.2006.12.022, 2007.

Timmermann, T., Margóczi, K., Takács, G., and Vegelin, K.: Restoration of peat-forming vegetation by rewetting species poor fen grassland, Appl. Veg. Sci., 9, 241-250, doi:10.1111/j.1654109X.2006.tb00673.x, 2006.

Tyson, K. C., Garwood, E. A., Armstrong, A. C., and Scholefield, D.: Effect of field drainage on the growth of herbage and the liveweight gain of grazing beef cattle, Grass Forage. Sci., 47, 290-301, doi:10.1111/j.1365-2494.1992.tb02273.x, 1992.

UBA: National Inventary Report for the German Greenhouse Gas Inventory 1990-2012, Submission under the United Nations
Framework Convention on Climate Change and the KyotoProtocol 2014, UBA, Dessau-Roßlau, 2014.

van Beek, C. L., Pleijter, M., Jacobs, C. M., Velthof, G. L., van Groenigen, J. W., and Kuikman, P. J.: Emissions of $\mathrm{N}_{2} \mathrm{O}$ from fertilized and grazed grassland on organic soil in relation to groundwater level, Nutr. Cycl. Agroecosys., 86, 331-340, doi:10.1007/s10705-009-9295-2, 2010.

van Beek, C. L., Pleijter, M., and Kuikman, P. J.: Nitrous oxide emissions from fertilized and unfertilized grasslands on peat soil, Nutr. Cycl. Agroecosys., 89, 453-461, doi:10.1007/s10705-0109408-y, 2011.

van den Pol-van Dasselaar, A., van Beusichem, M. L., and Oenema, O.: Effects of grassland management on the emission of methane from intensively managed grasslands on peat soil, Plant Soil, 189, 1-9, doi:10.1023/A:1004219522404, 1997.

van den Pol-van Dasselaar, A., van Beusichem, M. L., and Oenema, O.: Determinants of spatial variability of methane emissions from wet grasslands on peat soil, Biogeochemistry, 44, 221-237, doi:10.1023/A:1006009830660, 1999.

van der Weerden, T. J., Clough, T. J., and Styles, T. M.: Using near continuous measurements of $\mathrm{N}_{2} \mathrm{O}$ emissions from urine-affected soil to guide manual gas sampling regimes, New Zeal. J. Agr. Res., 56, 60-76, doi:10.1080/00288233.2012.747548, 2013.

van Groenigen, J. W., Velthof, G. L., Oenema, O., van Groenigen, K. J., and van Kessel, C.: Towards an agronomic assessment of $\mathrm{N}_{2} \mathrm{O}$ emissions: A case study for arable crops, Eur. J. Soil Sci., 61, 903-913, doi:10.1111/j.1365-2389.2009.01217.x, 2010.

VDLUFA: Methodenbuch Band I, Die Untersuchung von Böden, VDLUFA, Speyer, 1991.

Velthof, G. L. and Oenema, O.: Nitrous oxide fluxes from grassland in the Netherlands: I. Statistical analysis of flux-chamber measurements, Eur. J. Soil Sci., 46, 533-540, doi:10.1111/j.13652389.1995.tb01349.x, 1995a.

Velthof, G. L. and Oenema, O.: Nitrous oxide fluxes from grassland in the Nethetlands: II, Effects of soil type, nitrogen fertilizer application and grazing, Eur. J. Soil Sci., 46, 541-549, doi:10.1111/j.1365-2389.1995.tb01350.x, 1995b.

Verbeke, G. and Molenberghs, G.: Linear mixed models for longitudinal data, Springer, New York, 2000.

Waddington, J. M. and Roulet, N. T.: Atmosphere-wetland carbon exchanges: Scale dependency of $\mathrm{CO}_{2}$ and $\mathrm{CH}_{4}$ exchange on the developmental topography of a peatland, Global Biogeochem. Cy., 10, 233-245, doi:10.1029/95GB03871, 1996.

Weißbach, F., Schmidt, L., and Kuhla, S.: Simplified method for calculation of NEL from metabolizable energy, Proc. Soc. Nutr. Physiol., 5, 117, 1996.

Wohlfahrt, G., Anderson-Dunn, M., Bahn, M., Balzarolo, M., Berninger, F., Campbell, C., Carrara, A., Cescatti, A., Christensen, T., Dore, S., Eugster, W., Friborg, T., Furger, M., Gianelle, D., Gimeno, C., Hargreaves, H., Hari, P., Haslwanter, A., Johansson, T., Marcolla, B., Milford, C., Nagy, Z., Nemitz, E., Rogiers, N., Sanz, M. J., Siegwolf, R. T. W., Susiluoto, S., Sutton, M., Tuba, Z., Ugolini, F., Valentini, R., Zorer, R., and Cernusca, A.: Biotic, abiotic, and management controls on the net ecosystem $\mathrm{CO}_{2}$ exchange of European mountain grassland ecosystems, Ecosystems, 11, 1338-1351, doi:10.1007/s10021008-9196-2, 2008a.

Wohlfahrt, G., Hammerle, A., Haslwanter, A., Bahn, M., Tappeiner, U., and Cernusca, A.: Seasonal and inter-annual variability of 
the net ecosystem $\mathrm{CO}_{2}$ exchange of a temperate mountain grassland: Effects of weather and management, J. Geophys. Res., 113, D08110, doi:10.1029/2007JD009286, 2008b.

Xu, X.K., Duan, C.T., Wu, H.H., Li, T.S., and Chang, W.G.: Effect of intensity and duration of freezing on soil microbial biomass, extractable $\mathrm{C}$ and $\mathrm{N}$ pools, and $\mathrm{N}_{2} \mathrm{O}$ and $\mathrm{CO}_{2}$ emissions from forest soils in cold temperate region, Sci. China Ser. D, 59, 156169, doi:10.1007/s11430-015-5115-5, 2016.

Yrjälä, K., Tuomivirta, T., Juottonen, H., Putkinen, A., Lappi, K., Tuittila, E.-S., Penttilä, T., Minkkinen, K., Laine, J., Peltoniemi, K., and Fritze, $\mathrm{H} .: \mathrm{CH}_{4}$ production and oxidation processes in a boreal fen ecosystem after long-term water table drawdown, Glob. Change Biol., 17, 1311-1320, doi:10.1111/j.13652486.2010.02290.x, 2011.
Zak, D., Augustin, J., Trepel, M., and Gelbrecht, J.: Strategies for fen restoration and avoiding conflicts in the context of water, climate and nature protection in the lowlands of NE Germany, Telma, Supplement 4, 133-150, 2011. 